ORIGINAL ARTICLE

\title{
Improved tree height estimation of secondary forests in the Brazilian Amazon
}

\author{
Henrique Luis Godinho CASSOL ${ }^{1, *}$, Yosio Edemir SHIMABUKURO ${ }^{1}$, João Manuel de Brito CARREIRAS ${ }^{2}$, \\ Elisabete Caria MORAES ${ }^{1}$ \\ 1 Instituto Nacional de Pesquisas Espaciais - INPE, Divisão de Sensoriamento Remoto, São José dos Campos, SP, Brasil \\ ${ }^{2}$ University of Sheffield, National Centre for Earth Observation (NCEO), Sheffield, UK \\ *Corresponding author: henrique@dsr.inpe.br
}

\begin{abstract}
This paper presents a novel approach for estimating the height of individual trees in secondary forests at two study sites: Manaus (central Amazon) and Santarém (eastern Amazon) in the Brazilian Amazon region. The approach consists of adjusting tree height-diameter at breast height $(\mathrm{H}: \mathrm{DBH})$ models in each study site by ecological species groups: pioneers, early secondary, and late secondary. Overall, the $\mathrm{DBH}$ and corresponding height $(\mathrm{H})$ of 1,178 individual trees were measured during two field campaigns: August 2014 in Manaus and September 2015 in Santarém. We tested the five most commonly used log-linear and nonlinear $\mathrm{H}: \mathrm{DBH}$ models, as determined by the available literature. The hyperbolic model: $\mathrm{H}=a \cdot \mathrm{DBH} /(b+\mathrm{DBH})$ was found to present the best fit when evaluated using validation data. Significant differences in the fitted parameters were found between pioneer and secondary species from Manaus and Santarém by F-test, meaning that site-specific and also ecological-group $\mathrm{H}$ :DBH models should be used to more accurately predict $\mathrm{H}$ as a function of $\mathrm{DBH}$. This novel approach provides specific equations to estimate height of secondary forest trees for particular sites and ecological species groups. The presented set of equations will allow better biomass and carbon stock estimates in secondary forests of the Brazilian Amazon.
\end{abstract}

KEYWORDS: tree height-diameter $(\mathrm{H}: \mathrm{DBH})$ model; nested model; indicative variable; height growth; ecological species groups

\section{Estimativa melhorada de altura de árvores em florestas secundárias da Amazônia brasileira}

\section{RESUMO}

Este trabalho apresenta uma nova abordagem para a estimativa de altura de árvores em florestas secundárias em duas áreas de estudo na Amazônia brasileira: Manaus (Amazônia central) e Santarém (Amazônia oriental). A abordagem consistiu em ajustar modelos hipsométricos separados por área de estudo e grupos ecológicos de espécies: pioneiras, secundárias iniciais e secundárias tardias. No total, 1178 árvores foram medidas em diâmetro e altura em duas etapas de campo: agosto de 2014 em Manaus e Setembro de 2015 em Santarém. Foram testados cinco modelos log-lineares e não lineares mais utilizados na literatura. $\mathrm{O}$ modelo hiperbólico: $\mathrm{H}=a \cdot \mathrm{D} /(b+\mathrm{D})$ foi o que apresentou o melhor ajuste quando avaliado com os dados de validação. Diferenças significativas nos parâmetros de ajuste foram observadas entre as espécies pioneiras e secundárias de Manaus e Santarém pelo teste F, significando que equaçóes específicas por grupos ecológicos e área de estudo deveriam ser utilizadas para estimar a altura (H) a partir do diâmetro (D) com maior acurácia. Esta nova abordagem fornece equaçôes específicas para localidade e grupo ecológico, para estimar a altura das árvores em florestas secundárias. O conjunto de equaçóes desenvolvidas permitirá melhorar as estimativas de biomassa e a quantificação dos estoques de carbono nas florestas secundárias da Amazônia brasileira.

PALAVRAS-CHAVE: modelos hipsométricos; modelos aninhados; variável indicadora; taxa de crescimento em altura; grupos ecológicos de espécies

CITE AS: Cassol, H. L. G.; Shimabukuro, Y. E.; Carreiras, J. M. B.; Moraes, E. C. 2018. Improved tree height estimation of secondary forests in the Brazilian Amazon. Acta Amazonica 48: 179-190. 


\section{INTRODUCTION}

In the Amazon region, height-diameter at breast height (H:DBH) models are important because dense forest understory makes it difficult and time-consuming to view the top of the canopy to measure the tree heights. Several $\mathrm{H}: \mathrm{DBH}$ models have been proposed for old-growth tropical forests for that purpose (Feldpausch et al. 2011; 2012; Hunter et al. 2013), however, they are scarce for secondary forests (Lucas et al. 2002; Neeff and Santos 2005). For instance, Lucas et al. (2002) used genus-specific nonlinear models to estimate tree height based on diameter for the most common species from a secondary forest in Manaus (central Amazon). Conversely, Neeff and Santos (2005) estimated tree height, and its increments, at stand-level age based on the BertalanffyChapman-Richards model in a secondary forest in Santarém (eastern Amazon). Other models related to $\mathrm{H}: \mathrm{DBH}$ include the logistic, Weibull, and Richards models (Fang and Bailey 1998; Huang et al. 2000).

The choice of the best model, however, depends on the relation between tree height and $\mathrm{DBH}$, which, in turn, can be associated with physical and biological factors at tree- and stand-level (Poorter and Bongers 2006; Weiskittel et al. 2011). At tree level, H:DBH scaling may be represented by the stemform factor, which can be indicative of the tree's position within the forest stand (Weiskittel et al. 2011). The stem-form factor is defined as the ratio of the volume of a tree, or its part, to the volume of a cylinder with the same size (height) and cross section (DBH). Therefore, the tree may present a conical or cylindrical shape depending on its stem-form factor. For example, dominant trees often have a $\mathrm{DBH}$ greater than 30 $\mathrm{cm}$, enjoy favorable light conditions, and have cylindrical shapes (Assmann 1970). In these trees, the scaling exponent between $\mathrm{H}$ and $\mathrm{DBH}$ is equal or similar to two-thirds, and the allometry assumes an elastic similarity model (Norberg 1988). Meanwhile, most sub-dominant and pioneer species follow a geometric similarity model $(\mathrm{H}: \mathrm{DBH}$ scaling $=1.0)$, i.e., the trunk diameter will scale in direct proportion to the tree height (Sposito and Santos 2001). However, when H:DBH scaling -2.0 there is a constant stress model, which is commonly caused by wind or other stresses (Sposito and Santos 2001).

At stand level, tree growth depends on forest structure, dominance type, tree density, species composition, and site environmental conditions (Weiskittel et al. 2011). Therefore, tree growth rate and $\mathrm{H}: \mathrm{DBH}$ scaling are influenced by environmental conditions and functional traits at both tree and stand levels (Selaya et al. 2008; Chazdon 2014). Sites with nutrient-rich soils and favorable climate conditions promote fast tree growth; pioneer species seek these resources in order to quickly colonize newly deforested areas (Chazdon 2014). The tree-height growth is highest at sites with better quality of environmental conditions, even though the maximum increase could be reached at the same age in poor sites (Weiskittel et al.
2011). Several studies have been carried out to develop sitebased H:DBH models exploring these different environmental conditions in varying forest types (Pillsbury et al. 1995; Huang et al. 2000; Feldpausch et al. 2011). Huang et al. (2000) noted that the application of $\mathrm{H}: \mathrm{DBH}$ models from one region to another may result in an average bias of $29 \%$.

Different species make use of distinct strategies to reach sunlight, promoting fast or slow growth, depending on resource availability and plant physiology (Poorter et al. 2012). In Amazonian secondary forests dominated by Cecropia sp. and Vismia sp., the pioneer species showed fast growth and aboveground biomass (AGB) accumulation, reaching 110-115 $\mathrm{Mg} \mathrm{ha}^{-1}$ during the first 10-15 years (Lucas et al. 2002). As a strategy, these pioneer species intercept more light per unit leaf mass to support their fast growth than late successional species, contributing to the efficient conversion of mass to height (Selaya et al. 2008). To maintain rapid growth, pioneer species also present high leaf turnover in the upper-canopy, forming a monolayer leaf arrangement that covers bare soil. In contrast, these species need to form slender stems with low wood density to support such accelerated tree growth, which inevitably reduces their life span (Poorter and Bongers 2006; Selaya et al. 2008).

Late successional tree species are characterized by lower growth rates, resulting in the requirement for greater wood densities to support larger canopies and to reduce the risk of hollow stem formation (Poorter and Bongers 2006). These species are generally taller and long-lived when compared to pioneer species, although the photosynthetic rate by leaf mass is smaller (Chazdon 2014). Therefore, carbon assimilation by long-lived late successional species is lower and more persistent compared with short-lived pioneer species (Santiago et al. 2004). Such differences in vertical growth among species have significant implications for AGB accumulation in tropical forests (Feldpausch et al. 2011; Feldpausch et al. 2012). Tree height is highly variable in the Amazon forest, therefore it is important that this parameter is included in equations to estimate tree AGB more accurately (Lefsky et al. 2010; Chave et al. 2014; Sawada et al. 2015). Feldpausch et al. (2011) observed a tree height gradient from northeast to southwest Amazon, with the tallest trees in the Guiana Shield and the shortest in the southern Amazon. By including tree height in the AGB models, biomass estimates errors were consistently reduced from 66 to $48 \mathrm{Mg} \mathrm{ha}^{-1}$ from the eastern-central to the western Amazon, respectively (Feldpausch et al. 2012). Furthermore, the AGB of the Brazilian Amazon is often estimated by applying allometric equations generated from only primary or old-growth forest species, which may lead to overestimation (by 10-60\%) when applied for AGB secondary forest trees (Nelson et al. 1999).

In this study, we hypothesized that there are significant differences in $\mathrm{H}: \mathrm{DBH}$ relationships among ecological species groups, i.e., pioneer, early, and late secondary species. We 
also expected to find significant differences between groups of ecological species across the study sites owing to different environmental and climate conditions. It has been reported that maximum tree heights at stand level vary among primary forests across the Amazon (Feldpausch et al. 2011, 2012; Lefsky et al. 2010); however, it is unclear whether these differences also occur over secondary forests. For this investigation, we evaluated five commonly used $\mathrm{H}: \mathrm{DBH}$ models adjusted to different ecological species groups occurring in two sites, with the aim of improving tree height estimation in secondary forests in the Brazilian Amazon.

\section{MATERIAL AND METHODS}

\section{Study area and data}

This study was carried out at two sites in the Brazilian Amazon: Manaus (Amazonas State) in the central Amazon region, and Santarém (Pará State) in the eastern Amazon region. At the Manaus site, the sampling plots were chosen on either side of the BR-174 highway, $70 \mathrm{~km}$ to the north of the city of Manaus. At the Santarém site, the sampling plots were chosen close to the Tapajós National Forest (FLONA Tapajós) on either side of the BR-163 highway, $100 \mathrm{~km}$ to the south of the city of Santarém (Figure 1).

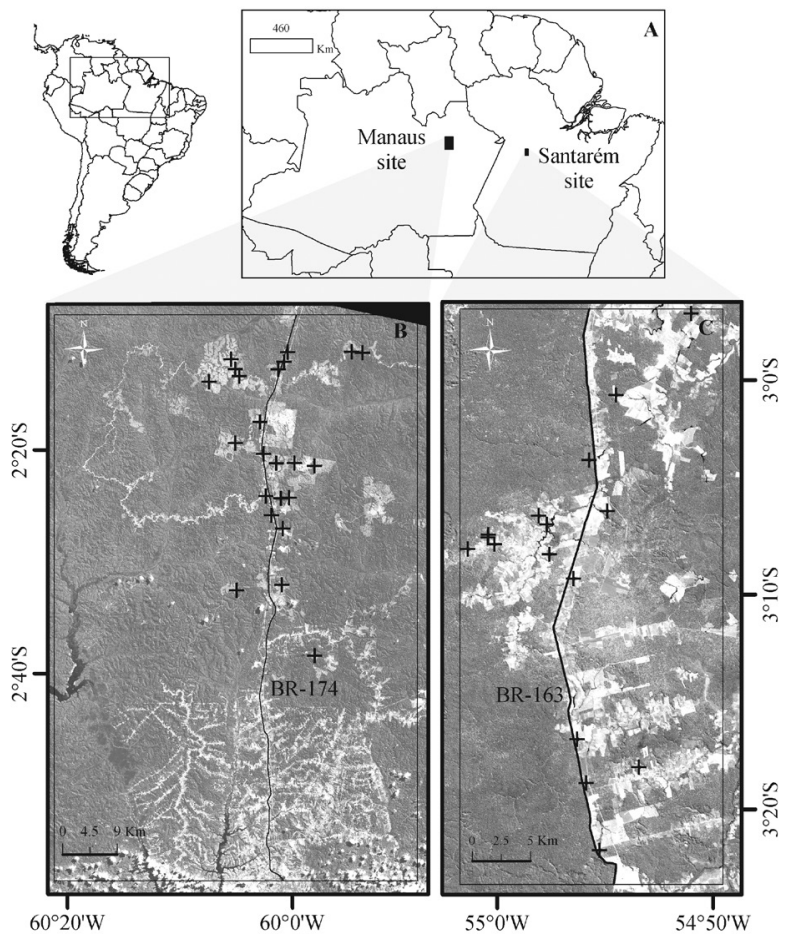

Figure 1. Geographical distribution of the study sites. A. Map of South America detailing the geographical position of study sites of the REGROWTH-BR project (rectangles) in Amazonas and Pará states, Brazil. B. Distribution of plots in the Manaus site (triangles) on either side of the BR-174 highway, $70 \mathrm{~km}$ to the north of the city of Manaus. C. Distribution of plots in the Santarém site (triangles) on either side of the BR-163 highway, 100 km to the south of the city of Santarém.
According to Chave et al. (2005), both study sites are classified as 'moist forest', with less than 5 months averaging $<100 \mathrm{~mm} \mathrm{month}^{-1}$ of rainfall during the dry season. The dry season length is shorter in Manaus (3.1 months) than in Santarém (4.5 months) (Malhi et al. 2004). Manaus receives an average annual rainfall of $2,200 \mathrm{~mm}$, which is slightly higher than that received at Santarém $(2,000 \mathrm{~mm})$ (Asner et al. 2003). The mean annual temperature at both sites is approximately $26^{\circ} \mathrm{C}$. Soils are predominantly nutrient-poor clay oxisols with some sandy ultisols (Silver et al. 2000).

Secondary forests in Manaus and Santarém occur in a region dominated by terra firme old-growth dense forests, which have a similar average canopy height $(26$ and 28 $\mathrm{m}$, respectively), but very different height distributions (Hunter et al. 2015). Santarém primary forests present a bi-modal distribution of tree-canopy heights, one comprised of emergent trees (average 35-40 m heights) and the other comprised of sub-dominant trees (average 15-30 m), while Manaus primary forests show a near unimodal Gaussian distribution, with an average $26 \mathrm{~m}$ canopy height (Hunter $e t$ al. 2015). Additionally, open tropical forests occur in the east side of FLONA Tapajos, with these being widely dominated by palm trees such as babaçú (Attalea speciosa Mart.) and inajá (A. maripa (Aubl.) Mart.) on sandy soils (Prates-Clark et al. 2009; personal observation).

In both study sites, only advanced secondary forests (age $>16$ years) were measured in a $60 \times 100 \mathrm{~m}$ nested plot. All sampling plots were randomly selected based on the age of the secondary forest and on land-use history (period of active land use and frequency of land clearance), assessed through the analysis of extensive Landsat sensor time-series data (Carreiras et al. 2014). Field measurements were conducted during August 2014 in Manaus (23 plots) and September 2015 in Santarém (16 plots) (Figure 1) as part of the REGROWTHBR project (Carreiras et al. 2014).

All trees with a DBH (at $1.3 \mathrm{~m}$ height) greater than or equal to $5 \mathrm{~cm}$ were measured within a $10 \times 100 \mathrm{~m}$ plot. Trees with a $\mathrm{DBH} \geq 10 \mathrm{~cm}$ were measured within a $20 \times 100 \mathrm{~m}$ plot, and trees with a $\mathrm{DBH} \geq 20 \mathrm{~cm}$ were measured within a $60 \times 100 \mathrm{~m}$ plot. All trees were identified botanically to species level or marked as unknown (three cases; see Supplementary Material, Table S1).

Trees were randomly selected and heights were measured at each nested plot (circa 25 measurements per plot) with a laser hypsometer (True Pulse 200 ${ }^{\mathrm{TM}}$, LaserInc Technology, Denver, CO, USA), whereas DBH was measured with a girth tape. All trees with broken or damaged crowns, and all palms, were excluded from the analysis.

The individuals were assigned to an ecological species group (ESG): pioneers (P), early secondary stage (ES), or late secondary stage (LS). This was based on the information collected from the literature and from the Global Wood Density Database (Zanne et al. 2009, see Supplementary 
Material, Table S1). The formal Mann-Whitney U test was used to compare differences between wood densities among the three ESGs. The Bonferroni correction for pair-wise Mann-Whitney U test alpha was $\alpha / 3=\sim 0.0167$. Therefore, we used median wood density thresholds to assign a species to a specific ESG when the previous classification was not found in the literature, e.g., pioneers $\leq 0.5 \mathrm{~g} \mathrm{~cm}^{-3}, 0.5 \mathrm{~g} \mathrm{~cm}^{-3}<$ early secondary $\leq 0.59 \mathrm{~g} \mathrm{~cm}^{-3}$, and late secondary $<0.74 \mathrm{~g} \mathrm{~cm}^{-3}$.

Height and $\mathrm{DBH}$ data from 1,178 individual trees ranging from $5-70 \mathrm{~cm}$ in diameter, corresponding to 188 species and 52 families, were collected during the field campaign: 529 individuals in Manaus and 649 in Santarém. Before adjusting $\mathrm{H}: \mathrm{DBH}$ models, the data were stratified by ecological species and study site, and then split into two subsets: the training subset (80\%) for model fitting, and the remainder (testing subset) for model validation (Table 1). The H:DBH ratio was evaluated by study site using the Mann-Whitney $\mathrm{U}$ test to support a priori any difference in tree architecture (Feldpausch et al. 2011). The Mann-Whitney $\mathrm{U}$ test was performed using the $\mathrm{R}$ statistical program (R Development Core Team 2008).

\section{Model selection and comparison of fitted models}

Several linear and nonlinear allometric models have been proposed to describe the relationship between tree height and diameter (Fang and Bailey 1998; Huang et al. 2000). In this study, we tested five widely used H:DBH models (Fang and Bailey 1998; Huang et al. 2000; Feldpausch et al. 2011) (Table 2). Only $\mathrm{H}: \mathrm{DBH}$ models with up to three parameters were selected in order to avoid problems with over-parameterization in nonlinear regression estimation, as reported by Fang and Bailey (1998).

To select the most suitable model, we compared the ability of these five allometric models to predict tree height at each ESG by study site. The nonlinear least squares $(n l s)$ command from $\mathrm{R}$ was used to estimate the parameters in all nonlinear models (Bates and Watts 1990), and the ordinary least squares ( $(\mathrm{m})$ command in the case of the log-linear model (m1).
The following statistics were used to select the best models in terms of goodness-of-fit using the training subset (Motulsky and Christopoulos 2003): (i) absolute and relative root mean square error (RMSE); and (ii) Akaike information criterion (AIC) weights (Wagenmakers and Farrel 2004). The relationship between standardized residuals and predicted height was evaluated visually through scatterplots in each model to account for heteroskedasticity. Additionally, a formal Breusch-Pagan test against heteroskedasticity (Neter $\mathrm{et}$ al. 1996) was performed using the lmtest package in $\mathrm{R}$.

\section{Model validation and presence of outliers}

Prediction bias was calculated by subtracting the predicted height from the observed height (measured) using the testing subset. A null hypothesis, whereby the bias is equal to zero, was tested by t-test, with $\alpha=0.05$ significance level. Therefore, the root mean square error of prediction (RMSEP) was calculated by Eq. (1) (Hastie et al. 2009): RMSEP $=\left(\right.$ bias $^{2}+$ variance $^{1 / 2}$. The first term in Eq. (1) is relative to the average prediction bias and the second term refers to the variance-bias, which in turn, is related to the spread of points around the mean prediction.

The presence of outliers was evaluated in both training and testing subsets using outlier in the "outliers" package of $\mathrm{R}$ program. The presence of outliers was verified by observing the spread of the residuals. If confirmed, the model selection and validation were iteratively repeated to improve model fitting. This process was performed twice with removal of 19 outliers from the analysis, including the training and testing subsets.

We arbitrary attributed a descending rank order to choose only one model based on highest AIC weight: value 5 for the best model (highest), and 1, for the worst (lowest). The best ranked fitted model (sum of rank values) was then used to analyze differences between ESG and study sites using an indicator regression approach.

Table 1. Summary of the training and validation datasets (in parentheses) by study area and ecological species groups (ESG). $N=$ number of trees, min $=$ minimum, $\max =$ maximum, $\mathrm{SD}=$ standard deviation, $\mathrm{DBH}=$ diameter at breast height, $\mathrm{P}$ - pioneers, $\mathrm{ES}$ - early secondary, $\mathrm{LS}$ - late secondary.

\begin{tabular}{|c|c|c|c|c|c|c|c|c|c|c|}
\hline \multirow{2}{*}{ Study area } & \multirow{2}{*}{ ESG } & \multirow{2}{*}{ N } & \multicolumn{4}{|c|}{$\mathrm{DBH}(\mathrm{cm})$} & \multicolumn{4}{|c|}{ Total height (m) } \\
\hline & & & $\min$ & $\max$ & mean & SD & $\min$ & $\max$ & mean & SD \\
\hline \multirow{4}{*}{ Manaus } & $P$ & $253(65)$ & $5.0(5.1)$ & $56.0(40.3)$ & $20.9(20.2)$ & $8.9(8.3)$ & $2.0(7.6)$ & $28.3(23.7)$ & $16.8(16.5)$ & $4.4(4.1)$ \\
\hline & ES & $96(24)$ & $5.0(5.5)$ & $34.0(26.5)$ & $15.4(14.3)$ & $7.8(6.7)$ & $5.2(6.7)$ & $28.6(27.4)$ & $15.0(14.2)$ & $5.6(5.5)$ \\
\hline & LS & $73(18)$ & $5.1(5.0)$ & $42.4(32.3)$ & $15.8(17.3)$ & $10.5(9.7)$ & $5.1(3.0)$ & $31.7(27.1)$ & $13.9(15.4)$ & $6.6(7.6)$ \\
\hline & All & $422(107)$ & $5.0(5.0)$ & $56.0(40.3)$ & $18.8(18.3)$ & $9.3(8.5)$ & $2.0(3.0)$ & $31.7(27.4)$ & $15.9(15.7)$ & $5.2(5.1)$ \\
\hline \multirow{4}{*}{ Santarém } & $P$ & $208(50)$ & $5.0(5.0)$ & $57.0(47.8)$ & $18.0(19.2)$ & $10.8(10.2)$ & $3.4(7.0)$ & $28.0(28.0)$ & $15.8(16.1)$ & $5.9(5.8)$ \\
\hline & ES & $172(42)$ & $5.0(5.2)$ & $56.0(26.6)$ & $12.4(11.3)$ & $8.9(5.9)$ & $5.5(7.2)$ & $28.7(24.7)$ & $12.5(12.3)$ & $4.9(4.4)$ \\
\hline & LS & $142(35)$ & $5.0(5.2)$ & $70.0(64.2)$ & $15.2(16.6)$ & $12.4(12.8)$ & $5.3(5.4)$ & $29.0(26.0)$ & $13.2(14.1)$ & $5.2(5.3)$ \\
\hline & All & $521(128)$ & $5.0(5.0)$ & $70.0(64.2)$ & 15.4 (15.9) & 10.9 (10.4) & $3.4(5.4)$ & $29.0(28.0)$ & $14.0(14.3)$ & $5.6(5.5)$ \\
\hline
\end{tabular}


Table 2. Height-diameter models selected for analysis. $\mathrm{H}=$ total height $(\mathrm{m})$; $\mathrm{DBH}$ = diameter at breast height (1.3 $\mathrm{m}$ above ground).

\begin{tabular}{lcc}
\hline Model number & Model form & Model type \\
\hline m1 & $\mathrm{H}=a+b \cdot \log . \mathrm{DBH}$ & Log-Linear \\
m2 & $\log \mathrm{H}=a+b \cdot \log . \mathrm{DBH}$ & Log-Log \\
m3 & $\mathrm{H}=a \cdot \mathrm{DBH} /(b+\mathrm{DBH})$ & Hyperbolic \\
m4 & $\mathrm{H}=a \cdot\left(1-c \cdot \exp \mathrm{p}^{(-b . \mathrm{DBH})}\right)$ & Monomolecular \\
m5 & $\mathrm{H}=a \cdot\left(1-\exp (b . \mathrm{DBH})^{c}\right)$ & Chapman-Richards \\
\hline
\end{tabular}

\section{Comparison of $\mathrm{H}: \mathrm{DBH}$ models by ecological species group and study site}

The indicator regression approach was used to evaluate full and reduced nested models with a simple ANOVA F-test (Bates and Watts 1990; Neter et al. 1996). The indicator variable, or dummy variable, is an artificial variable created to represent an attribute with two or more distinct categories/levels, which, in our case, was represented by a study site or a specific ESG (Neter et al. 1996).

In the full model, the indicator variable could only take the values 0 and 1, corresponding to each study site or ESG, and the reduced model was fitted using the whole dataset without the indicator variable. However, to avoid over-parametrization of the full models, the ANOVA F-test was performed to compare each pair of ESGs per study site, because the difference in parameter estimation may be caused by only two or more indicator variables involved in the analysis, and this method reduces the number of parameters whilst retaining validation of the nested approach (Huang et al. 2000).

For instance, if the response function was modeled by the loglinear model between pioneers and early secondary forest species, the full-model of $\mathrm{H}: \mathrm{DBH}$ would have three parameters (Neter $e t$ al. 1996) [Eq. (2): $h=a+b \log (\mathrm{DBH})+c G 1 \log (\mathrm{DBH})+\varepsilon$; where $a$ and $b$ are log-linear parameters, $c$ represents the parameters related to indicator variable, and $\varepsilon$ is the regression error; G1 refers to the indicator variable of a specific ESG (pioneer or early secondary)]. In this case, the reduced model has only two parameters $(a$ and $b$ ). Considering that the response function (2) is for pioneers for which $G 1=0$, then the model would take the form: $b=a+b \log (\mathrm{DBH})$. If the response function is for early secondary species for which $G 1=1$, then Eq. (2) would take the form: $h=a+b \log (\mathrm{DBH})+c G 2 \log (\mathrm{DBH})$, and so on. Similarly, the analysis can be performed with all nonlinear models described in Table 1, and with all other ESG pairs or study sites.

The equality of the two models was tested by considering the null hypothesis, $H_{0}$, whereby indicator parameters in the full model are equal to zero, against the alternative hypothesis, $H_{1}$, whereby at least one parameter differs from zero using the F-test according to Motulsky and Christopoulos (2003). ANOVA F-test was performed in $\mathrm{R}$ (R Core Team 2008) with a 0.95 confidence level.
Finally, we estimated the relative growth height rate (HGR) by taking the derivative of the selected model by its diameter. The fitted curves for relationships between HGR and H:DBH were provided.

\section{RESULTS}

\section{Ecological species groups}

Median differences in wood density between ESG pairs differed from zero (Mann-Whitney $U$ test: $W=64, p<$ $0.016)$, suggesting that wood density values could be used to separate species groups. Then, we used median wood density to assign species into an ESG when these were not available in the literature (in this case 22 of 323 species collected, Supplementary Material, Table S1).

Wood density outliers, marked with an open circle in Figure 2, indicate the low wood density of Hevea brasiliensis (Willd. ex A. Juss.) Müll.Arg. (0.40 $\mathrm{g} \mathrm{cm}^{-3}$, late secondary species) in Manaus. In Santarém, outliers were represented by high wood density of Neea oppositifolia Ruiz \& Pav. (0.89 g $\mathrm{cm}^{-3}$, pioneer species) and Sloanea nitida G. Don. $\left(0.96 \mathrm{~g} \mathrm{~cm}^{-3}\right.$, early secondary species), and low wood density of Jacaratia spinosa (Aubl.) A.DC. (0.14 $\mathrm{g} \mathrm{cm}^{-3}$, early secondary species).

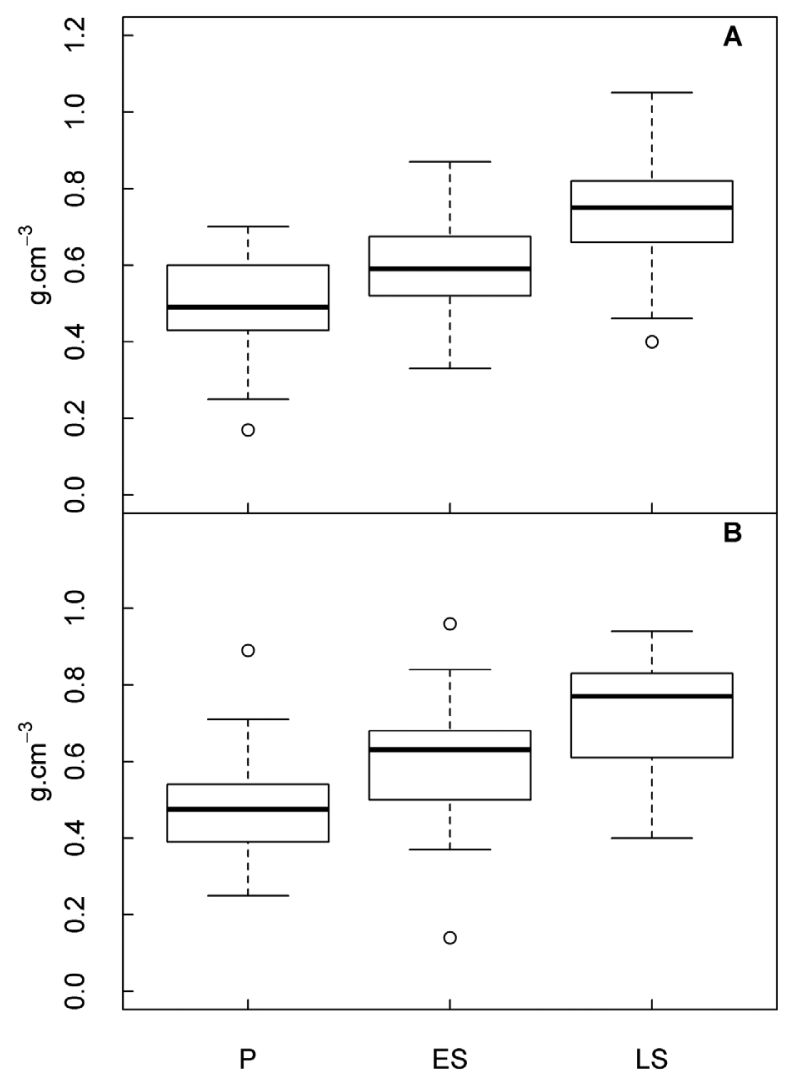

Figure 2. Distribution of wood density $\left(\mathrm{g} \mathrm{cm}^{-3}\right)$ by ecological species groups: (P) pioneer, (ES) early secondary, and (LS) late secondary species in secondary forests. A - Wood density values from Manaus species; B - Wood density values from Santarém species. 
The simple ratio $\mathrm{H}: \mathrm{DBH}$ of the secondary forest trees was significantly different between study sites, as determined by the Mann-Whitney U test: $\mathrm{W}=133246, \mathrm{p}<0.001$ (Manaus $=0.9037 ;$ Santarém $=1.0588)$. Tree diameters from secondary forests in Manaus (median $19.8 \mathrm{~cm}$ ) were significantly different from those in Santarém (median $12.2 \mathrm{~cm}$ ), and the same was observed for tree heights in Manaus (median $16.7 \mathrm{~m}$ ) and Santarém (median $12.8 \mathrm{~m}$ ), $\mathrm{p}<0.001$. This indicates that the $\mathrm{H}: \mathrm{DBH}$ relationship followed a different distribution at each study site, considering that forests at both study sites are of similar average age (circa 23 years after clear cut).

\section{Models' goodness-of-fit}

Two-parameter models showed the best goodness-of-fit given by the sum ranked order of the lowest AIC (Table 3): hyperbolic model (sum of 21 points) and log-log model (19 points). The monomolecular model (18 points) also had a low AIC among the three-parameter models. All regression parameters were significant at $\alpha=0.05$ for all models, with the exception of the Weibull model for early secondary species in Manaus, the Chapman-Richards model for early secondary species in Santarém, and for late secondary species in Manaus (Table 3).

Table 3. Fitting statistics of the tested H:DBH models by ecological species groups and study area. RMSE and RMSE are the absolute and relative root mean square error, respectively. RMSEP is the RMSE of prediction. R is the value of the rank order based on the lowest wiAIC (in bold). wiAIC - weights of Akaike information criterion; $\mathrm{BP}$ - Breusch-Pagan test. *Non-significant parameters for alpha $=0.05$. NC - do not converge.

\begin{tabular}{|c|c|c|c|c|c|c|c|c|c|c|}
\hline \multirow{2}{*}{ Model } & \multicolumn{3}{|c|}{ Regression parameter } & \multirow{2}{*}{ RMSE (m) } & \multirow{2}{*}{ RMSE (\%) } & \multirow{2}{*}{ AlC } & \multirow{2}{*}{$\begin{array}{l}\text { wi } \\
\text { AlC }\end{array}$} & \multirow{2}{*}{$\begin{array}{l}\text { RMSEP } \\
(\mathrm{m})\end{array}$} & \multirow{2}{*}{$\mathrm{R}$} & \multirow{2}{*}{$p$-value B } \\
\hline & a & $b$ & c & & & & & & & \\
\hline Manaus & & \multicolumn{9}{|c|}{ Ecological Species Group $=1$ (Pioneers) train. $n=255$ test $n=63$} \\
\hline m1 & -3.67 & 6.97 & & 2.61 & 15.55 & 1207.36 & 0.618 & 2.62 & 5 & 0.41 \\
\hline m3 & 29.12 & 13.65 & & 2.62 & 15.58 & 1208.68 & 0.319 & 2.59 & 4 & 0.64 \\
\hline m5 & 23.74 & 0.05 & 0.76 & 2.63 & 15.62 & 1212.89 & 0.039 & 2.58 & 3 & 0.76 \\
\hline m4 & 22.73 & 0.92 & 0.07 & 2.64 & 15.72 & 1213.95 & 0.023 & 2.56 & 2 & 0.24 \\
\hline $\mathrm{m} 2$ & 0.66 & 0.44 & & 2.68 & 15.92 & 1219.99 & 0.001 & 2.73 & 1 & 0.68 \\
\hline Manaus & & \multicolumn{9}{|c|}{ Ecological Species Group $=2$ (Early Secondary) train. $n=96$ test $n=24$} \\
\hline $\mathrm{m} 2$ & 0.44 & 0.64 & & 2.52 & 16.78 & 444.61 & 0.672 & 3.07 & 5 & 0.19 \\
\hline m4 & $55.16^{*}$ & 0.93 & $0.016^{*}$ & 2.54 & 16.89 & 446.80 & 0.225 & 3.09 & 4 & 0.65 \\
\hline m3 & 43.97 & 27.21 & & 2.57 & 17.18 & 448.48 & 0.097 & 3.03 & 3 & 0.88 \\
\hline $\mathrm{m} 1$ & -8.18 & 8.95 & & 2.65 & 17.65 & 454.20 & 0.006 & 3.07 & 2 & 0.25 \\
\hline m5 & NC & NC & & $N C$ & NC & $N C$ & NC & NC & 1 & NC \\
\hline Manaus & & \multicolumn{9}{|c|}{ Ecological Species Group $=3$ (Late Secondary) train. $n=73$ test $n=18$} \\
\hline $\mathrm{m} 2$ & 0.41 & 0.63 & & 2.96 & 21.25 & 359.68 & 0.456 & 2.93 & 5 & 0.14 \\
\hline m3 & 43.08 & 28.84 & & 2.98 & 21.50 & 360.65 & 0.282 & 2.80 & 4 & 0.07 \\
\hline m4 & 37.60 & 0.93 & 0.03 & 2.97 & 21.29 & 360.91 & 0.247 & 2.87 & 3 & 0.04 \\
\hline m1 & -8.30 & 8.75 & & 3.11 & 22.29 & 366.43 & 0.016 & 2.95 & 2 & 0.05 \\
\hline m5 & 32.22 & $0.031^{*}$ & 0.81 & 3.15 & 22.48 & 379.58 & 0.000 & 2.94 & 1 & 0.01 \\
\hline Santarém & & \multicolumn{9}{|c|}{ Ecological Species Group $=1$ (Pioneers) train. $n=208$ test $n=50$} \\
\hline m4 & 30.90 & 0.94 & 0.04 & 2.52 & 15.99 & 965.94 & 0.446 & 3.09 & 5 & 0.16 \\
\hline m3 & 40.95 & 25.21 & & 2.53 & 16.08 & 966.78 & 0.293 & 3.11 & 4 & 0.38 \\
\hline m5 & 31.46 & 0.04 & 0.84 & 2.53 & 16.04 & 967.02 & 0.260 & 3.14 & 3 & 0.63 \\
\hline m1 & -8.78 & 9.02 & & 2.61 & 16.52 & 978.35 & 0.001 & 3.17 & 2 & 0.62 \\
\hline $\mathrm{m} 2$ & 0.53 & 0.55 & & 2.61 & 16.52 & 979.29 & 0.001 & 3.07 & 1 & 0.25 \\
\hline Santarém & & \multicolumn{9}{|c|}{ Ecological Species Group $=2$ (Early Secondary) train. $n=172$ test $n=42$} \\
\hline $\mathrm{m} 2$ & 0.53 & 0.53 & & 2.34 & 18.74 & 780.48 & 0.371 & 1.86 & 5 & 0.42 \\
\hline m5 & 37.22 & $0.02^{*}$ & 0.62 & 2.34 & 18.72 & 780.77 & 0.321 & 1.80 & 4 & 0.49 \\
\hline m4 & 30.28 & 0.88 & 0.04 & 2.34 & 18.77 & 781.80 & 0.192 & 1.77 & 3 & 0.26 \\
\hline m3 & 33.66 & 18.16 & & 2.36 & 18.98 & 783.36 & 0.088 & 1.75 & 2 & 0.78 \\
\hline m1 & -5.08 & 7.53 & & 2.38 & 19.04 & 785.59 & 0.029 & 1.83 & 1 & 0.79 \\
\hline Santarém & & \multicolumn{9}{|c|}{ Ecological Species Group $=3$ (Late Secondary) train. $n=142$ test $n=35$} \\
\hline m1 & -3.46 & 6.74 & & 2.38 & 18.03 & 643.95 & 0.699 & 2.32 & 5 & 0.14 \\
\hline m3 & 29.19 & 14.50 & & 2.41 & 18.27 & 647.21 & 0.137 & 2.30 & 4 & 0.32 \\
\hline m5 & 28.78 & 0.02 & 0.59 & 2.40 & 18.21 & 647.83 & 0.101 & 2.37 & 3 & 0.16 \\
\hline $\mathrm{m} 2$ & 0.61 & 0.46 & & 2.43 & 18.39 & 649.91 & 0.036 & 2.49 & 2 & 0.21 \\
\hline $\mathrm{m} 4$ & 25.79 & 0.85 & 0.04 & 2.43 & 18.40 & 650.50 & 0.027 & 2.37 & 1 & 0.04 \\
\hline
\end{tabular}


The visualization of standardized residuals against predicted height showed the absence of heteroskedasticity (Figure 3), which further supports the non-significant results of the Breusch-Pagan test (Table 3). The residuals were drawn only for the selected hyperbolic model.

Based on the ranked model (Table 3), the hyperbolic model (m3) presented satisfactory results for all ESGs without being the best for a specific ESG. The prediction error of the hyperbolic model extended from RMSEP $=1.75$ to $3.11 \mathrm{~m}$ (Table 3). Considering that bias is close to zero by the null hypothesis, we did not reject $H_{0}$ in any of the ESG cases, meaning that the average bias was equal to zero with $d_{f F}(n-1)$ degrees of freedom. Because the mean bias was not significantly different from zero in all models fitted by a one sample t-test ( $p>0.05)$, variance of prediction was a large source of error. In general, the hyperbolic model performed well, although it overestimated tree height above $20 \mathrm{~m}$, independent of age, as this seems to be the height at which this model begins to consistently underestimate values (Figure 4).

\section{Comparison of $\mathrm{H}-\mathrm{DBH}$ models by study site and ESG}

The null hypothesis was not rejected for the ESG 2-3 pair (early secondary and late secondary species) at both study sites (Table
4), suggesting that parameters $c$ and $d$ from the full models were different from zero in these cases $(p>0.05)$. Based on the results of the paired F-test, and the estimated parameters of the full model, we concluded that secondary species (early and late) had a similar $\mathrm{H}: \mathrm{DBH}$ relationship in both study sites, hereafter grouped into one class, while pioneer species belonged to another class.

We compared the differences in the H:DBH relationships of these new groups (pioneers and secondary species) by study site, in order to determine whether tree growth was also influenced by geographic location. A clear difference in the $\mathrm{H}: \mathrm{DBH}$ relationship between pioneer and secondary species from Manaus and Santarém by statistical inference (Table 5) was strengthened by the low p-value obtained by the F-test. $\mathrm{H}: \mathrm{DBH}$ models for the pioneer species took the form: $h=$ $29.12 \mathrm{DBH} /(13.65+\mathrm{DBH})$ for Manaus, and $h=40.94 \mathrm{DBH} /$ $(25.21+\mathrm{DBH})$ for Santarém (Table 5). Similarly, secondary species took the form: $h=42.84 \mathrm{DBH} /(27.05+\mathrm{DBH})$ for Manaus, and $h=30.83 \mathrm{DBH} /(15.81+\mathrm{DBH})$ for Santarém. Model adjustments for pioneer and secondary species for Manaus and Santarém are provided in Figure 5.

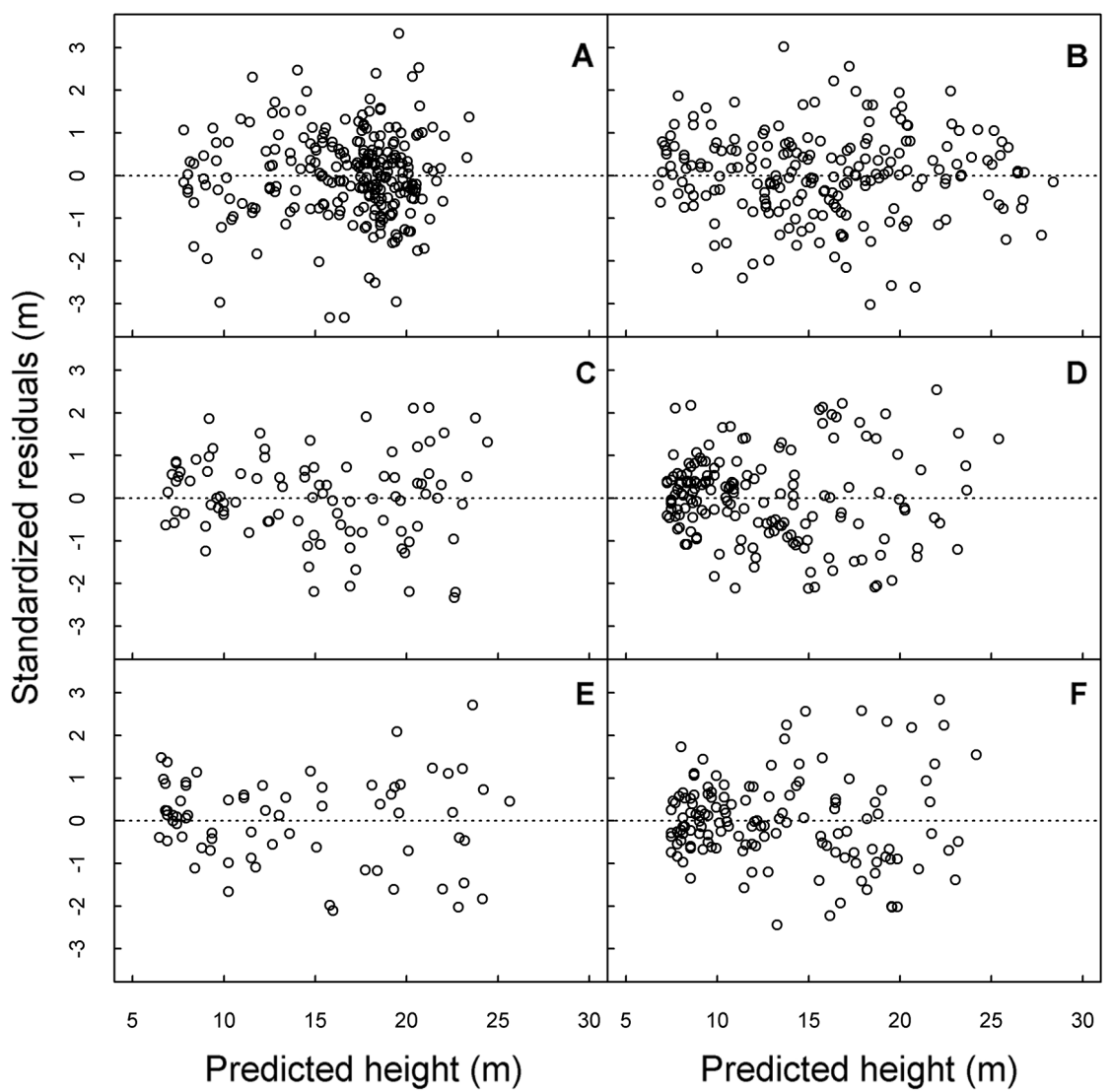

Figure 3. Plots of standardized residuals against predicted height using nonlinear least squares fitting of the hyperbolic model for pioneer (A), early secondary (C), and late secondary (E) species in Manaus and Santarém ( $\mathrm{B}, \mathrm{D}$, and F), respectively. 


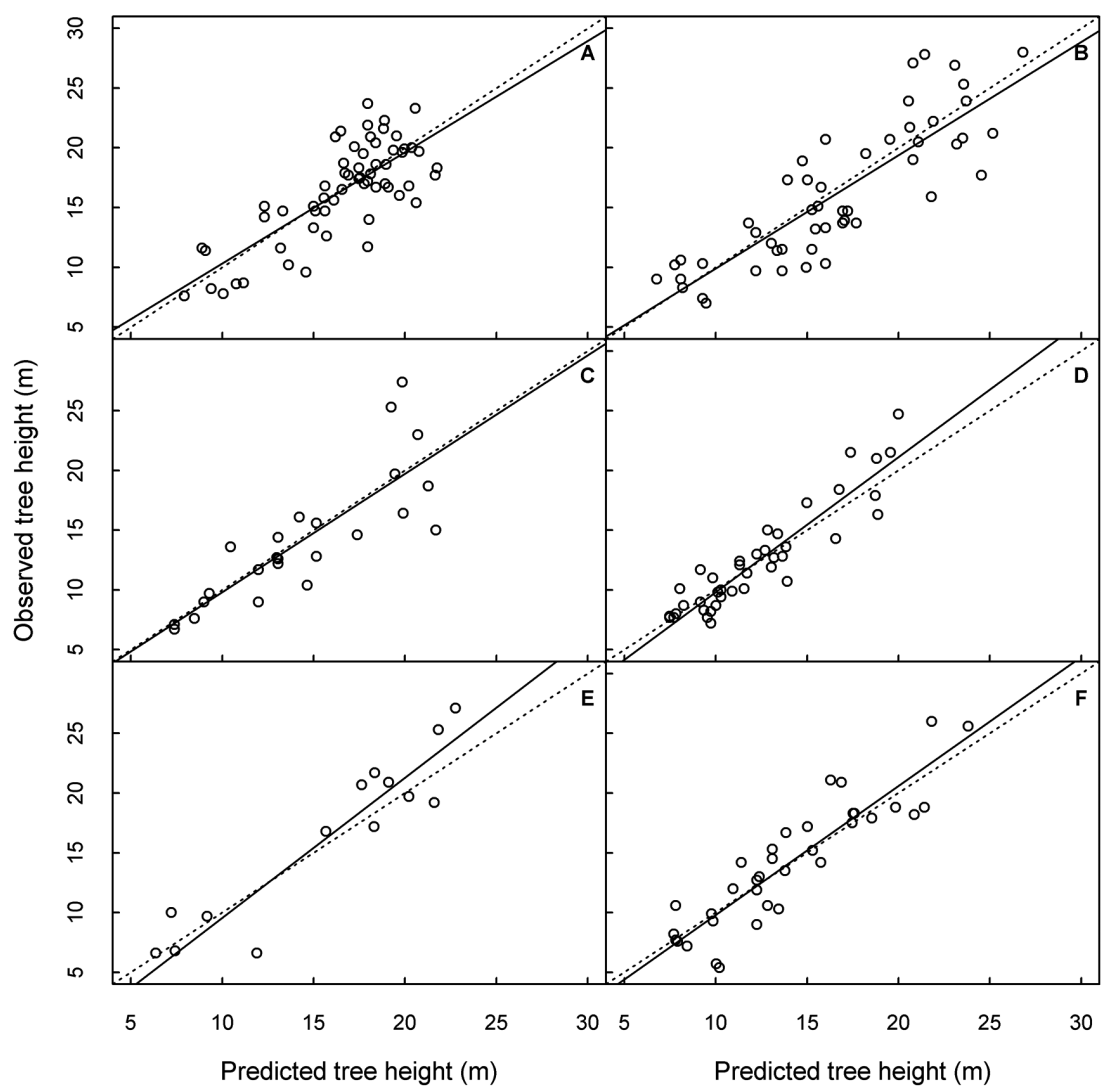

Figure 4. Scatterplot of observed vs. predicted tree heights using the validation subset for pioneer (A, B), early secondary (C, D) and late secondary (E, F) species from Manaus ( $A, C$, and $E$ ) and Santarém ( $B, D$, and F). Observed vs. predicted height is fitted using a continuous line; the dashed line refers to the perfect agreement (1:1).

Table 4. Fitted parameters of the full ( $F$ ) and reduced (R) hyperbolic model by ESG pairs. $\mathrm{Cl}=95 \%$ confidence interval, as shown in parentheses. SSE (F) and SSE (R) are the sum of square error for full and reduced models, respectively. $a, b, c$, and $d$ are the parameters. ESG-Pair (ecological species group pairs): 1-2 (pioneers-early secondary species), 1-3 (pioneers-late secondary species), 2-3 (early-late secondary species).

\begin{tabular}{|c|c|c|c|c|c|c|c|c|}
\hline \multicolumn{9}{|l|}{ Manaus } \\
\hline $\begin{array}{l}\text { ESG } \\
\text { pair }\end{array}$ & $\begin{array}{c}\mathrm{a} \\
\text { (Cl) }\end{array}$ & $\begin{array}{c}\mathrm{b} \\
(\mathrm{Cl})\end{array}$ & $\begin{array}{c}\mathrm{C} \\
(\mathrm{Cl})\end{array}$ & $\begin{array}{c}d \\
(\mathrm{Cl})\end{array}$ & $\begin{array}{l}\text { SSE (F)/ } \\
\text { SSE (R) }\end{array}$ & $n$ & $F_{0}$ & $\begin{array}{c}p \text {-value } \\
(>F)\end{array}$ \\
\hline $1-2 F$ & $29.12(2.58)$ & 13.65 (3.12) & $14.84(12.24)$ & $13.56(12.93)$ & 2328.00 & 347 & 11.36 & $<0.001$ \\
\hline $1-2 R$ & $30.92(2.45)$ & $15.34(2.87)$ & & & 2482.30 & & & \\
\hline $1-3 F$ & $29.12(2.68)$ & $13.65(3.24)$ & $13.96(11.31)$ & 15.19 (13.37) & 2332.40 & 324 & 7.84 & $<0.001$ \\
\hline $1-3 R$ & $31.88(2.76)$ & $16.88(3.33)$ & & & 2446.70 & & & \\
\hline $2-3 F$ & $43.97(13.05)$ & $27.21(13.76)$ & $-0.88(14.02)$ & $1.63(15.90)$ & 1223.40 & 163 & 1.84 & 0.161 \\
\hline $2-3 R$ & $42.84(7.42)$ & $27.05(8.14)$ & & & 1251.50 & & & \\
\hline \multicolumn{9}{|c|}{ Santarém } \\
\hline $\begin{array}{l}\text { ESG } \\
\text { pair }\end{array}$ & $\begin{array}{c}a \\
\text { (Cl) }\end{array}$ & $\begin{array}{c}\mathrm{b} \\
(\mathrm{Cl})\end{array}$ & $\begin{array}{c}\mathrm{C} \\
\text { (Cl) }\end{array}$ & $\begin{array}{c}d \\
\text { (Cl) }\end{array}$ & $\begin{array}{l}\text { SSE (F)/ } \\
\text { SSE (R) }\end{array}$ & $n$ & F0 & $\begin{array}{c}p \text {-value } \\
(>\mathrm{F})\end{array}$ \\
\hline $1-2 \mathrm{~F}$ & $40.95(3.99)$ & $25.21(4.54)$ & $-7.29(5.28)$ & $-7.05(5.52)$ & 2245.90 & 376 & 3.71 & 0.025 \\
\hline $1-2 R$ & 38.31 (2.79) & $22.47(3.02)$ & & & 2290.80 & & & \\
\hline $1-3 \mathrm{~F}$ & $40.95(4.04)$ & $25.21(4.60)$ & $-11.76(4.43)$ & $-10.71(4.88)$ & 2101.70 & 345 & 17.04 & $<0.001$ \\
\hline $1-3 R$ & $35.44(2.46)$ & $19.94(2.76)$ & & & 2311.70 & & & \\
\hline $2-3 F$ & $33.66(3.91)$ & $18.16(3.89)$ & $-4.47(4.25)$ & $-3.66(4.31)$ & 1743.00 & 311 & 2.69 & 0.069 \\
\hline $2-3 R$ & $30.83(2.14)$ & $15.81(2.20)$ & & & 1773.60 & & & \\
\hline
\end{tabular}


Table 5. Fitted parameters of full (F) and reduced (R) hyperbolic models by study area for pioneer and secondary species. $\mathrm{Cl}=95 \%$ confidence interval, as shown in parentheses. SSE (F) and SSE (R) are the sum of square error for full and reduced models, respectively. $a, b, c$, and d are the parameters.

\begin{tabular}{|c|c|c|c|c|c|c|c|c|}
\hline Groups & $\begin{array}{l}a \\
(C I)\end{array}$ & $\begin{array}{l}b \\
\text { (CI) }\end{array}$ & $\begin{array}{c}c \\
(C l) \\
\end{array}$ & $\begin{array}{c}d \\
(C l)\end{array}$ & $\begin{array}{l}\text { SSE }(F) / \\
\text { SSE }(R)\end{array}$ & $n$ & $F_{0}$ & $\begin{array}{c}p \text {-value } \\
(>F)\end{array}$ \\
\hline Pioneers F & $29.12(2.54)$ & $13.65(3.08)$ & $11.82(4.72)$ & $11.56(5.42)$ & 3020.80 & 458 & 19.105 & $p<0.001$ \\
\hline Pioneers $R$ & $34.15(2.40)$ & $18.89(2.83)$ & & & 3275.00 & & & \\
\hline Secondary F & $42.84(6.64)$ & $27.05(7.28)$ & $-12.01(5.55)$ & $-11.24(5.90)$ & 3025.10 & 476 & 12.463 & $p<0.001$ \\
\hline Secondary R & $34.00(2.19)$ & $18.56(2.30)$ & & & 3184.80 & & & \\
\hline
\end{tabular}

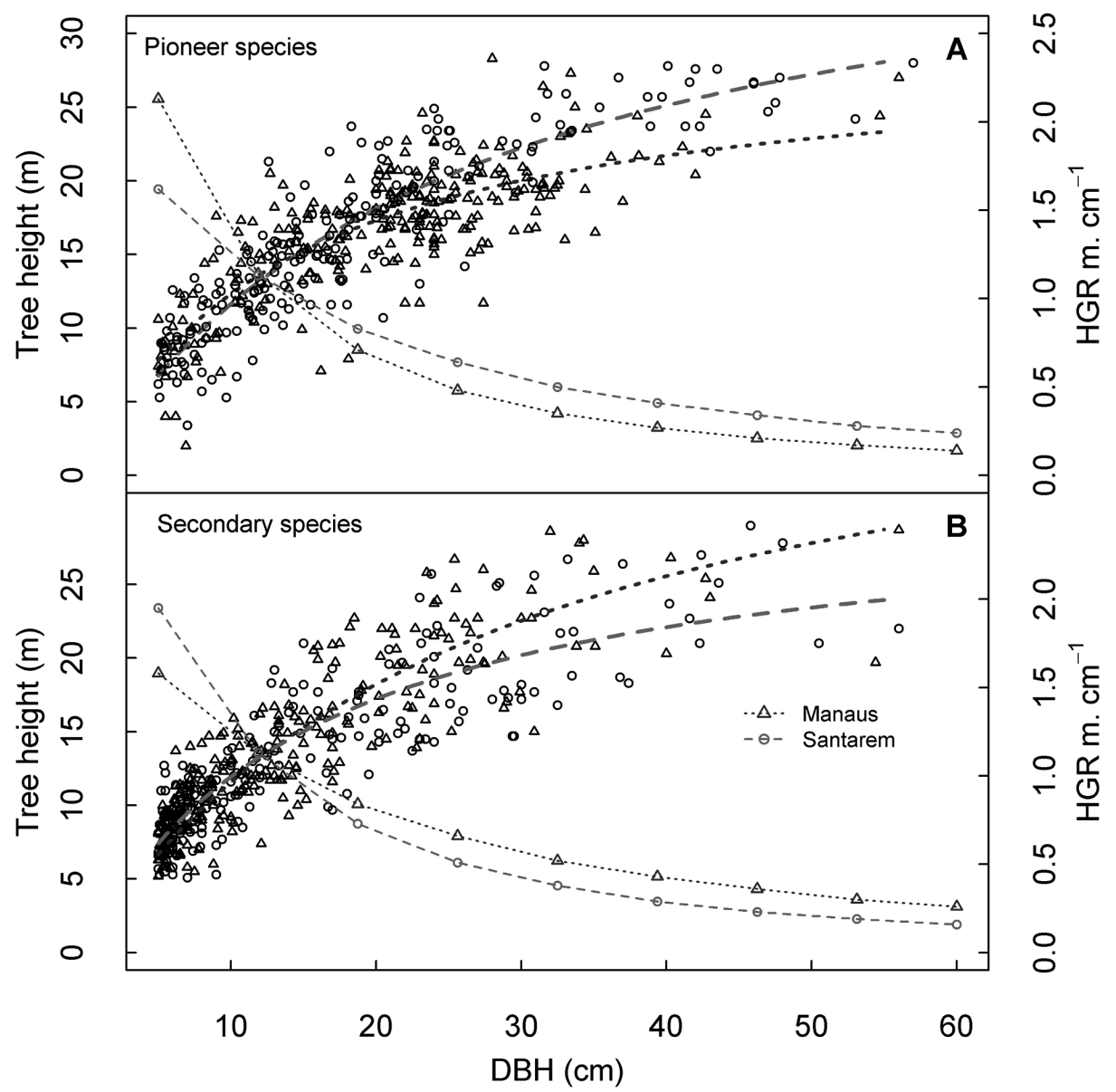

Figure 5. Scatterplot of the hyperbolic model adjustment between diameter and tree height on the primary $y$-axis, and between DBH and tree height growth rate on the secondary $y$-axis.

\section{Height growth by site and species groups}

The hyperbolic model was relatively easy to fit, achieved good validation results, and was meaningful in terms of the biological interpretation of its parameters. In this function, $a$ represents total height at maximum $\mathrm{DBH}$ (asymptote), and $b$ is the $\mathrm{DBH}$ when tree height reaches half the asymptote. Thus, a first derivative of the hyperbolic model allows us to obtain the absolute rate of height growth by DBH unit [Eq. (3): $d y /$ $\left.d x=a b /(b+\mathrm{x})^{2}\right]$. Therefore, when DBH approaches zero, $a / b$ represents the maximum height increment by DBH unit ( $\mathrm{m}$ $\mathrm{cm}^{-1}$ ). Disregarding other underlying dynamic processes of $\mathrm{H}: \mathrm{DBH}$ relationships, we observed that pioneers in Manaus had the highest HGR. The HGR in pioneer species from Manaus was $2.13 \mathrm{~m} \mathrm{~cm}^{-1}$, meaning that for every centimeter in diameter increment, height increased more than $2 \mathrm{~m}$. Santarém pioneers had a HGR $=1.62 \mathrm{~m} \mathrm{~cm}^{-1}$ (Figure 5). Conversely, secondary species in Santarém had a greater HGR than those in Manaus, HGR $=1.95$ and $1.58 \mathrm{~m} \mathrm{~cm}^{-1}$, respectively. 
Pioneer species had high initial HGR in Manaus compared with secondary species, and this decreased with increasing diameter. Compared with Manaus, pioneer species in Santarém showed a greater HGR for large trees (Figure 5). The increase in height growth fell below $0.20 \mathrm{~m} \mathrm{~cm}^{-1}$ at DBH $>40 \mathrm{~cm}$. This decline can be expected to continue until the regenerating forest becomes structurally similar to the average canopy heights of the mature forest, which is reported to be $26 \mathrm{~m}$ in Manaus and 28 $\mathrm{m}$ in Santarém (Hunter et al. 2015). Based on height modelling of secondary forests in Santarém, height initially increases by a maximum of $2 \mathrm{~m}$ per year, and then falls below $0.25 \mathrm{~m}$ per year at age 30 (Neeff and Santos 2005). Pioneer species in Manaus exhibited fast growth in the first years; this was around 30\% higher than that observed in Santarém (Figure 5). However, later in life, they had about 50\% smaller HGR than pioneers in Santarém $(\mathrm{DBH}=-40 \mathrm{~cm})$.

\section{DISCUSSION}

The hyperbolic model presented the best validation results among the most common models. We found statistical differences between pioneer and secondary species for $\mathrm{H}: \mathrm{DBH}$ relationships, but not between early and late secondary species. These differences were consistent across sites, probably due to environmental and climate conditions. The HGR presented distinct behavior among ESGs and between sites.

\section{Model selection for goodness-of-fit comparison}

According to Fang and Bailey (1998), different H:DBH models with the same number of parameters usually result in similar goodness-of-fit when the nonlinear least square method is used on the same data set. Feldpausch et al. (2011) observed that log-log models (two parameters) were the most suitable for estimating tree height in dry and wet forests, with no trend observed in their residuals by diameter class. Asymptotic functions with three parameters, such as the Weibull model, provided good estimates of ecologically meaningful $\mathrm{H}$ max in moist forests (Feldpausch et al. 2011). Conversely, when one or two parameters are introduced in the model (e.g., three or four parameters instead of two), biological interpretation of parameters may be lost (Fang and Bailey 1998). Convergence could not be attained as easily as when using the Weibull and Chapman-Richards models (Table 3).

In this study, the hyperbolic model was found to produce the most satisfactory fit among the tested models, which was consistent with previous studies that also satisfactorily tested this model for adjusting H:DBH relationships (Fang and Bailey 1998; Huang et al. 2000). Nevertheless, due to the adjusted asymptote being close to $40 \mathrm{~m}$ for secondary forest trees, the hyperbolic model tended to underestimate the height of large trees, therefore its application in old growth forest should be avoided.

\section{Separating H:DBH models by study site and ESG}

Statistical differences were found between study sites in $\mathrm{H}: \mathrm{DBH}$ relationships. Considering that the secondary forest plots were at a similar age ( -23 years), the most important local factors influencing $\mathrm{H}: \mathrm{DBH}$ relationships are the stand density, basal area, and species composition (Gómez-García et al. 2016). Basal area and stand density are the first parameters to reach similarity in mature forests (within 20-40 years), while similarity in species composition can take longer (Feldpausch et al. 2005; Neeff and Santos 2005).

Owing to resource competition, trees of the same DBH usually have greater height in denser stands. We estimated average stand basal area as 22.3 and $23.7 \mathrm{~m}^{2} \mathrm{ha}^{-1}$ in secondary forest plots in Santarém and Manaus, respectively, which may be indicative of greater average tree height in Manaus. Hunter et al. (2013) reported a greater average basal area of primary forests in FLONA Tapajós $\left(31 \mathrm{~m}^{2} \mathrm{ha}^{-1}\right)$, with average canopy height taller than that in Reserva Ducke, near Manaus site $\left(28.7 \mathrm{~m}^{2} \mathrm{ha}^{-1}\right)$. Such differences are probably due to primary forests from Santarém having larger trees with DBH $>60 \mathrm{~cm}$ than Manaus primary forests (Vieira et al. 2005), increasing both the average basal area and the mean canopy height, which is not observed in secondary forests.

Some climatic variables, such as greater annual precipitation, shorter dry season length, and greater mean annual air temperature, could be drivers of greater relative tree growth in central Amazon secondary forests (Malhi et al. 2004). From a hydraulic perspective, it would be expected that, for a given $\mathrm{DBH}$, trees would be shorter with increasing water deficit. Hence, the application of $\mathrm{H}: \mathrm{DBH}$ models from the moderately seasonal central Amazon may overestimate tree height in the dry forest, and underestimate it in the wet regions (Malhi et al. 2004).

Regarding ESG-specific H:DBH models, pioneer and secondary species may be regarded as different groups at our study sites. Although pioneer species grow faster than late successional species (Selaya $e t$ al. 2008), we found a different behavior in pioneer species in Santarém. In this study site, pioneer species showed similar behavior to early secondary species, which can be supported by interpretation of the magnitude of the confidence intervals of the regression parameters in Table 4.

Pioneer species were prevalent in Manaus with regard to their importance in species composition (\% of total species number), and their relative coverage (by summing relative density and dominance in the stand level). In Manaus, pioneer species comprised $33 \%$ of species richness, and $52 \%$ of the total stand trees, while in Santarém, they represented 29\% and $39 \%$, respectively. The monodominance of pioneer species such as Cecropia spp. and Vismia spp., which form a monolayer canopy arrangement, may prevent the recruitment of taller and later secondary species in Manaus (Lucas et al. 2002). 
It is probable that pioneer species from Santarém are still competing for resources with other secondary trees, while in Manaus, short-lived species are being replaced by other long-lived secondary species. The most important pioneer species in Manaus, Vismia spp., Cecropia spp., and Bellucia spp., are short-lived (20-30 years), and are virtually absent from old growth forest (Lucas et al. 2002). Secondary forests in Santarém are dominated almost exclusively by Guatteria poeppigiana Mart., a pioneer species with a lifespan of 54 years (Holm et al. 2014). The high growth rate of large trees $(\mathrm{DBH}>60 \mathrm{~cm}$ ) of late secondary species may be a major cause of faster carbon assimilation in the eastern Amazon than in the central Amazon (Vieira et al. 2005).

\section{CONCLUSIONS}

Among the models tested, the hyperbolic model presented the best performance for estimating tree height through diameter measured for secondary forests located near the cities of Manaus (central Amazon) and Santarém (eastern Amazon). In addition, we presented an alternative method of analyzing the height-diameter (H:DBH) relation of secondary forests species, separating them by ESGs. The results suggest that pioneer and secondary species belong to distinct groups in terms of H:DBH relationships, and that tree height growth differs between both study sites. Pioneer species from Manaus showed rapid tree height growth at low DBH compared with secondary species, while in Santarém the opposite trend was observed. We showed that separate H:DBH models are required to achieve more accurate predictions of tree height in secondary forests in Manaus and Santarém. These new $\mathrm{H}: \mathrm{DBH}$ models are essential to provide improved estimation of tree height in secondary forests, as required for carbon stock estimation (Chave et al. 2014; Poorter et al. 2016).

\section{ACKNOWLEDGMENTS}

We thank José Luís Camargo and Niro Higuchi for permitting entry to the Biological Dynamics of Forest Fragments Project (BDFFP) and Biomass and Nutrient Experiment Projetct (BIONTE) sites near Manaus; and Elisângela Rabelo for permitting entry to LBA-Santarém. We also thank the campaign contributors Richard Lucas, Joana Melo, Joshua Jones, Egídio Arai, Virgílio Pereira, Letícia Kirsten, and taxonomic experts who identified plant material in this study: Movido, Francisco (Caroço), Graveto, and Chico. This work was supported by the Tropical Research Institute (IICT) [PTDC/AGR-CFL/114908, 2009] and the Conselho Nacional de Desenvolvimento Científico e Tecnológico (CNPq) [400349, 2012-4], which encompassed expenses for the fieldwork in Manaus and Santarém, respectively.

\section{REFERENCES}

Asner G.P.; Bustamante, M.M.C.; Townsend, A.R. 2003. Scale dependence of biophysical structure in deforested areas bordering the Tapajo's National Forest, Central Amazon. Remote Sensing of Environment, 87: 507-520.

Assmann, E. 1970. The principles of forest yield studies. Pergamon Press, Oxford. 504p.

Bates, D.M.; Watts, D.G. 1990. Nonlinear Regression Analysis and Its Applications, 2nd ed. John Wiley \& Sons, Inc., New York, 365p.

Carreiras, J.M.B.; Jones, J.; Lucas, R.M.; Gabriel, C. 2014. Land use and land cover change dynamics across the Brazilian Amazon: insights from extensive time-series analysis of remote sensing data. PLoS One, 9: e104144.

Chave, J.; Andalo, C.; Brown, S.; Cairns, M. A.; Chambers, J. Q.; Eamus, D. et al. 2005. Tree allometry and improved estimation of carbon stocks and balance in tropical forests. Oecologia, 145: 87-99.

Chave, J.; Réjou-Máchain, M.; Búrquez, A.; Chidumayo, E.; Colgan, M. S.; Delitti, W. B. C. et al. 2014. Improved allometric models to estimate the aboveground biomass of tropical trees. Global Change Biology, 20: 3177-3190.

Chazdon, R.L. 2014. Second Growth: The promise of Tropical Forest Regeneration in an Age of Deforestation, Chicago Press, Chicago. $472 \mathrm{p}$.

Fang, Z.; Bailey, R.L. 1998. Height-diameter models for tropical forests on Hainan Island in southern China. Forest Ecology and Management, 110: 315-327.

Feldpausch, T.R.; Riha, S.J.; Fernandes, E.C.M.; Wandelli, E.V. 2005. Development of forest structure and leaf area in secondary forests regenerating on abandoned pastures in Central Amazônia. Earth Interactions. 9: 1-22.

Feldpausch, T.R.; Banin, L.; Phillips, O.L.; Baker, T.R.; Lewis, S.L.; Quesada, C.A. et al. 2011. Height-diameter allometry of tropical forest trees. Biogeosciences, 8: 1081-1106.

Feldpausch, T.R.; Lloyd, J.; Lewis, S.L.; Brienen, R.J.W.; Gloor, W.; Mendoza, A.M. et al. 2012. Tree height integrated into pantropical biomass forest estimates. Biogeosciences, 9: 33813403.

Gómez-García, E.; Fonseca, T.; Crecente-Campo, F.; Almeida, L.; Diéguez-Aranda, U.; Huang, S. et al. 2016. Height-diameter models for maritime pine in Portugal: a comparison of basic, generalized and mixed-effects models. iForest - Biogeosciences Forestry, 9: 72-78.

Hastie, T.; Tibshirani, R.; Friedman, J.H. 2009. The elements of statistical learning: data mining, inference, and prediction. 2nd ed. Springer, New York. 745p.

Holm, J.A.; Chambers, J.Q.; Collins, W.D.; Higuchi, N. 2014. Forest response to increased disturbance in the central Amazon and comparison to western Amazonian forests. Biogeosciences, 11: 5773-5794.

Huang, S.; Price, D.J.; Titus, S. 2000. Development of ecoregionbased height-diameter models for white spruce in boreal forests. Forest Ecology and Management, 129: 125-141. 
Hunter, M.O.; Keller, M.; Victoria.; Morton, D.C. 2013. Tree height and tropical forest biomass estimation. Biogeosciences, 10: 8385-8399.

Hunter, M.O.; Keller, M.; Morton, D.; Cook, B.; Lefsky. M.; Ducey. M. et al. 2015. Structural Dynamics of Tropical Moist Forest Gaps. PLoS One, 10: e0132144.

Lefsky, M.A. 2010. A global forest canopy height map from the Moderate Resolution Imaging Spectroradiometer and the Geoscience Laser Altimeter System. Geophysical Research Letters, 37: L15401.

Lucas, R.M.; Honzák, M.; Amaral, I.; Curran, P.J.; Foody, G.M.; 2002. Forest regeneration on abandoned clearances in central Amazonia. International Journal of Remote Sensing, 23: 965-988.

Malhi, Y.; Baker, T.R.; Phillips, O. L.; Almeida, S.; Alvarez, E.; Arroyo, L. et al. 2004. The above-ground coarse wood productivity of 104 Neotropical forest plots. Global Change Biology, 10: 563-591.

Motulsky, H.J.; Christopoulos, A. 2003. Fitting models to biological data using linear and nonlinear regression. GraphPad Software, Inc., San Diego, 352p.

Neeff, T.; Santos, J.R. 2005. A growth model for secondary forest in Central Amazonia. Forest Ecology and Management, 216: 270-282.

Nelson, B.W.; Mesquita, R.; Pereira, J.L.G.; De Souza, S.G.; Batista, G.T.; Couto, L.B. 1999. Allometric regressions for improved estimate of secondary forest biomass in the central Amazon. Forest Ecology and Management, 117: 149-167.

Neter, J.; Kutner, M.; Wasserman, W.; Nachtsheim, C. 1996. Applied Linear Statistical Models, 4th ed. McGraw-Hill, Irwin. 1396p.

Norberg, R.A. 1988. Theory of Growth Geometry of Plants and Self-Thinning of Plant Populations: Geometric Similarity, Elastic Similarity, and Different Growth Modes of Plant Parts. The American Naturalist, 131: 220-256.

Pillsbury, N.H.; McDonald, P.M.; Simon, V. 1995. Reliability of Tanoak volume equations when applied to different areas. Western Journal of Applied Forestry, 10: 72-78.

Poorter, L.; Bongers, F. 2006. Leaf traits are good predictors of plant performance across 53 rain forest species. Ecology, 87: $1733-1743$.

Poorter, H.; Niklas, K.J.; Reich, P.B.; Oleksyn, J.; Poot, P.; Mommer, L. 2012. Biomass allocation to leaves, stems and roots: metaanalyses of interspecific variation and environmental control. New Phytologist, 193: 30-50.
Poorter, L.; Bongers, F.; Aide, T.M.; Zambrano, A.M.A.; Balvanera P. Becknell, J.M. et al. 2016. Biomass resilience of Neotropical secondary forests. Nature, 530: 211-214.

Prates-Clark, C. da C.; Lucas, R.M.; dos Santos, J.R. 2009. Implications of land-use history for forest regeneration in the Brazilian Amazon. Canadian Journal of Remote Sensing, 35: 534-553.

R Development Core Team. 2008. R: A language and environment for statistical computing. (http://www.R-project.org). Accessed on $17 / 05 / 2015$.

Santiago, L.S.; Goldstein, G.; Meinzer, F.C.; Fisher, J.B.; Machado, K.; Woodruff, D. et al. 2004. Leaf photosynthetic traits scale with hydraulic conductivity and wood density in Panamanian forest canopy trees. Oecologia, 140: 543-550.

Sawada, Y.; Suwa, R.; Jindo, K.; Endo, T.; Oki, K.; Sawada, H. et al. 2015. A new 500-m resolution map of canopy height for Amazon forest using spaceborne LiDAR and cloud-free MODIS imagery. International Journal of Applied Earth Observation and Geoinformation, 43: 92-101.

Selaya, N.G.; Oomen, R.J.; Netten, J.J.C.; Werger, M.J.A.; Anten, N.P.R. 2008. Biomass allocation and leaf life span in relation to light interception by tropical forest plants during the first years of secondary succession. Journal of Ecology, 96: 1211-1221.

Silver, W.L.; Ostertag, R.; Lugo, A.E. 2000. The potential for carbon sequestration through reforestation of abandoned tropical agricultural and pasture lands. Restoration Ecology, 8: 394-407.

Sposito, T.C.; Santos, F.A.M. 2001. Scaling of Stem and Crown in Eight Cecropia (Cecropiaceae) Species of Brazil. American Journal of Botany, 88: 939-949.

Wagenmakers, E-J.; Farrell, S. 2004. AIC model selection using Akaike weights. Psychonomic Bulletin \& Review, 11: 192-196.

Weiskittel, A.; Hann, D.; Kershaw, J.; Vanclay, J. 2011. Forest growth and yield modelling. John Wiley \& Sons, Sussex, 430p.

Vieira, S.; Trumbore, S.; Camargo, P.B.; Selhorst, D.; Chambers, J.Q.; Higuchi, N. et al. 2005. Slow growth rates of Amazonian trees: Consequences for carbon cycling. Proceedings of the National Academy of Sciences, 102: 18502-18507.

Zanne, A.E.; Lopez-Gonzalez, G.; Coomes, D.A.; Ilic, J.; Jansen, S.; Lewis, S.L. et al. 2009. Global wood density database. Dryad. (http://hdl.handle.net/10255/dryad.235). Accessed on 22/10/2016.

RECEIVED: 20/03/2017

ACCEPTED: $23 / 03 / 2018$

ASSOCIATE EDITOR: Carolina Volkmer Castilho 
SUPPLEMENTARY MATERIAL (only available in the electronic version)

CASSOL et al. Improved tree height estimation of secondary forests in the Brazilian Amazon

Table S1. List of species and their respective botanical families recorded in this study. Scientific names according to http://www.theplantlist.org/; WD - wood density in gcm$^{-3}$; ESG - ecological species group: 1 - Pioneers, 2 - Early secondary, 3 - Late secondary/Climax, 4 - Exotic, 5 - Dead/Unknown; OCC - occurrence: 1 - Manaus, 2 - Santarem, 3 - Both; WD Ref - reference for wood density value; ESG Ref - reference for ecological species group.

\begin{tabular}{|c|c|c|c|c|c|c|c|}
\hline No & Family & Species & $\begin{array}{c}\text { WD } \\
\mathrm{gcm}^{-3}\end{array}$ & ESG & $\mathrm{OCC}$ & $\begin{array}{l}\text { WD } \\
\text { Ref }\end{array}$ & $\begin{array}{l}\text { ESG } \\
\text { Ref }\end{array}$ \\
\hline 1 & ACHARIACEAE & Lindackeria paludosa (Benth.) Gilg & 0.56 & 2 & 2 & 40 & 62 \\
\hline 2 & ANACARDIACEAE & Astronium lecointei Ducke & 0.79 & 3 & 2 & 40 & 43,17 \\
\hline 3 & & Spondias mombin $\mathrm{L}$. & 0.39 & 1 & 2 & 40 & 43 \\
\hline 4 & & Tapirira guianensis Aubl. & 0.46 & 1 & 3 & 40 & 74 \\
\hline 5 & & Thyrsodium spruceanum Benth. & 0.64 & 1 & 1 & 40 & 73 \\
\hline 6 & ANNONACEAE & Annona amazonica R.E.Fr. & 0.46 & 1 & 1 & 40 & \\
\hline 7 & & Annona ambotay Subl. & 0.46 & 2 & 1 & 40 & 68 \\
\hline 8 & & Annona foetida Mart. & 0.57 & 2 & 1 & 21 & 68 \\
\hline 9 & & Bocageopsis multiflora (Mart.) R.E.Fr. & 0.64 & 2 & 1 & 40 & 17 \\
\hline 10 & & Duguetia echinophora R.E.Fr. & 0.80 & 3 & 2 & 16 & 17 \\
\hline 11 & & Duguetia surinamensis R.E.Fr. & 0.80 & 3 & 1 & 40 & 17 \\
\hline 12 & & Ephedranthus amazonicus R.E.Fr. & 0.82 & 3 & 1 & 40 & 62 \\
\hline 13 & & Guatteria foliosa Benth. & 0.49 & 2 & 1 & 20 & 67 \\
\hline 14 & & Guatteria olivacea R.E.Fr. & 0.46 & 1 & 1 & 40 & 17 \\
\hline 15 & & Guatteria poeppigiana Mart. & 0.41 & 1 & 3 & $6,30,31$ & 43 \\
\hline 16 & & Guatteria scytophylla Diels & 0.52 & 2 & 1 & 40 & 67 \\
\hline 17 & & Rollinia insignis R.E. Fr. & 0.43 & 1 & 1 & 40 & 84 \\
\hline 18 & & Rollinia exsucca (DC. ex Dunal) A. DC. & 0.38 & 2 & 2 & 40 & 43 \\
\hline 19 & & Xylopia amazonica R.E.Fr. & 0.79 & 3 & 1 & 40 & \\
\hline 20 & & Xylopia nitida Dunal & 0.55 & 2 & 3 & 40 & 43,17 \\
\hline 21 & APOCYNACEAE & Ambelania acida Aubl. & 0.52 & 2 & 1 & 40 & 74 \\
\hline 22 & & Aspidosperma album (Vahl) Benoist ex Pichon & 0.77 & 3 & 2 & 40 & 75 \\
\hline 23 & & Aspidosperma nitidum Benth. ex Müll.Arg. & 0.76 & 3 & 3 & 40 & 43 \\
\hline 24 & & Aspidosperma schultesii Woodson & 0.78 & 3 & 1 & $9,38,40$ & \\
\hline 25 & & Geissospermum argenteum R. & 0.79 & 2 & 1 & 37 & 56,17 \\
\hline 26 & & Geissospermum sericeum Miers & 0.78 & 3 & 2 & 40 & 89 \\
\hline 27 & & Himatanthus stenophyllus Plumel & 0.53 & 2 & 1 & 40 & \\
\hline 28 & & Lacmellea aculeata (Ducke) Monach. & 0.48 & 3 & 2 & 40 & 43 \\
\hline 29 & & Lacmellea arborescens (Müll.Arg.) Markgr. & 0.48 & 2 & 1 & 40 & 31 \\
\hline 30 & & Rauvolfia sprucei Müll.Arg. & 0.54 & 2 & 1 & 38,40 & 79 \\
\hline 31 & ARALIACEAE & Schefflera morototoni (Aubl.) Maguire, Steyerm. \& Frodin & 0.43 & 1 & 3 & 40 & 17 \\
\hline 32 & ARECACEAE & Astrocaryum aculeatum G.Mey. & 0.40 & 2 & 2 & 13 & 43,56 \\
\hline 33 & & Astrocaryum vulgare Mart. & 0.45 & 1 & 2 & 40 & 43,97 \\
\hline 34 & & Attalea maripa (Aubl.) Mart. & 0.42 & 1 & 3 & 40,12 & 43 \\
\hline 35 & & Attalea speciosa Mart. & 0.52 & 1 & 2 & 12 & 77 \\
\hline 36 & & Elaeis oleifera (Kunth) Cortés & 0.64 & 4 & 1 & 35 & \\
\hline 37 & & Euterpe precatoria Mart. & 0.40 & 2 & 1 & 13 & 63 \\
\hline 38 & & Denocarpus bacaba Mart. & 0.47 & 1 & 3 & 40 & 43 \\
\hline 39 & & Oenocarpus minor Mart. & 0.68 & 3 & 1 & 40 & 43 \\
\hline 40 & & Syagrus coccoides Mart. & 0.60 & 2 & 2 & 40 & 43 \\
\hline 41 & & Syagrus inajai (Spruce) Becc. & 0.66 & 2 & 1 & 40 & 43 \\
\hline 42 & BIGNONIACEAE & Handroanthus serratifolius (Vahl) S.O.Grose & 0.94 & 3 & 3 & 40 & 43 \\
\hline 43 & & Handroanthus impetiginosus (Mart. ex DC.) Mattos & 0.90 & 3 & 2 & 40 & 43 \\
\hline 44 & & Jacaranda copaia (Aubl.) D.Don & 0.35 & 1 & 3 & 40 & 43,17 \\
\hline 45 & BIXACEAE & Bixa arborea Huber & 0.37 & 1 & 2 & 40 & 64 \\
\hline
\end{tabular}




\begin{tabular}{|c|c|c|c|c|c|c|c|}
\hline No & Family & Species & $\begin{array}{c}\text { WD } \\
\mathrm{gcm}^{-3}\end{array}$ & ESG & OCC & $\begin{array}{l}\text { WD } \\
\text { Ref }\end{array}$ & $\begin{array}{l}\text { ESG } \\
\text { Ref }\end{array}$ \\
\hline 46 & BORAGINACEAE & Cordia alliodora (Ruiz \& Pav.) Oken & 0.52 & 2 & 2 & 40 & 52,29 \\
\hline 47 & & Cordia bicolor A.DC. & 0.48 & 2 & 2 & 40 & 43,29 \\
\hline 48 & & Cordia exaltata Lam. & 0.40 & 1 & 1 & 40 & 43,75 \\
\hline 49 & & Cordia goeldiana Huber & 0.50 & 2 & 2 & 40 & 43,75 \\
\hline 50 & & Cordia nodosa Lam. & 0.39 & 2 & 1 & 40 & 31 \\
\hline 51 & BURSERACEAE & Protium altsonii Sandwith & 0.68 & 3 & 1 & 40 & 43 \\
\hline 52 & & Protium hebetatum D.C. Daly & 0.58 & 3 & 1 & 17 & 48 \\
\hline 53 & & Protium heptaphyllum (Aubl.) Marchand & 0.71 & 2 & 1 & 40 & 69,43 \\
\hline 54 & & Protium paniculatum Engl. & 0.65 & 3 & 2 & 40 & 47 \\
\hline 55 & & Protium puncticulatum J.F. Macbr. & 0.64 & 2 & 2 & 34 & 46 \\
\hline 56 & & Protium robustum (Swart) D.M.Porter & 0.68 & 2 & 2 & 16 & 56 \\
\hline 57 & & Protium nitidifolium (Cuatrec.) D.C. Daly & 0.62 & 2 & 1 & 20 & \\
\hline 58 & & Tetragastris altissima (Aubl.) Swart & 0.71 & 2 & 2 & 40 & 65 \\
\hline 59 & & Tetragastris panamensis (Engl.) Kuntze & 0.73 & 3 & 1 & 40 & 43 \\
\hline 60 & & Trattinnickia burserifolia Mart. & 0.46 & 3 & 3 & 40 & 43 \\
\hline 61 & CANNABACEAE & Trema micrantha (L.) Blume & 0.25 & 1 & 3 & 40 & 51 \\
\hline 62 & CARICACEAE & Jacaratia spinosa (Aubl.) A.DC. & 0.14 & 2 & 2 & 31 & 88 \\
\hline 63 & CARYOCARACEAE & Caryocar pallidum A.C.Sm. & 0.84 & 3 & 1 & 40 & 17 \\
\hline 64 & & Caryocar villosum (Aubl.) Pers & 0.76 & 3 & 3 & 40 & 43 \\
\hline 65 & CHRYSOBALANACEAE & Licania incana Aubl. & 0.86 & 3 & 2 & 40 & 43 \\
\hline 66 & & Licania micrantha Miq. & 0.84 & 3 & 1 & 40 & 43 \\
\hline 67 & & Licania oblongifolia Standl. & 0.80 & 3 & 1 & 40 & 17 \\
\hline 68 & & Licania prismatocarpa Spruce ex Hook.f. & 0.84 & 3 & 1 & $9,38,40$ & 67 \\
\hline 69 & CLUSIACEAE & Symphonia globulifera L.f. & 0.62 & 3 & 2 & 40 & 43 \\
\hline 70 & & Tovomita brasiliensis (Mart.) Walp. & 0.71 & 2 & 1 & 20 & 17 \\
\hline 71 & COMBRETACEAE & Buchenavia macrophylla Spruce ex Eichler & 0.82 & 3 & 1 & 38,40 & 17 \\
\hline 72 & CONNARACEAE & Connarus perrottetii (DC.) Planch. & 0.57 & 1 & 1 & 18 & 17 \\
\hline 73 & EBENACEAE & Diospyros manausensis Cavalcante & 0.72 & 3 & 1 & 38,40 & 31 \\
\hline 74 & ELAEOCARPACEAE & Sloanea nitida G. Don & 0.96 & 2 & 2 & 40 & 43 \\
\hline 75 & & Sloanea laurifolia (Willd.) Benth. & 0.82 & 2 & 1 & 40 & 43 \\
\hline 76 & EUPHORBIACEAE & Aparisthmium cordatum (A.Juss.) Baill. & 0.39 & 1 & 3 & 40 & 43 \\
\hline 77 & & Croton sp. & 0.47 & 1 & 2 & 40 & 17 \\
\hline 78 & & Croton matourensis Aubl. & 0.62 & 1 & 1 & 40 & 43 \\
\hline 79 & & Glycydendron amazonicum Ducke & 0.68 & 2 & 3 & 40 & 43 \\
\hline 80 & & Hevea guianensis Aubl. & 0.57 & 3 & 1 & 40 & 17 \\
\hline 81 & & Hevea brasiliensis (Willd. ex A.Juss.) Müll.Arg. & 0.40 & 3 & 3 & 40 & 43 \\
\hline 82 & & Joannesia heveoides Ducke & 0.39 & 2 & 2 & 40 & 78,47 \\
\hline 83 & & Mabea angularis Hollander & 0.61 & 2 & 1 & 38,40 & 17 \\
\hline 84 & & Mabea speciosa Müll.Arg. & 0.64 & 1 & 1 & 40 & 43 \\
\hline 85 & & Mabea subsessilis Pax \& K.Hoffm. & 0.60 & 2 & 1 & 40 & 45 \\
\hline 86 & & Maprounea guianensis Aubl. & 0.59 & 1 & 1 & 40 & 43 \\
\hline 87 & & Micrandra siphonioides Benth. & 0.58 & 2 & 1 & 40 & 57,99 \\
\hline 88 & & Nealchornea yapurensis Huber & 0.61 & 3 & 1 & 40 & 76 \\
\hline 89 & & Pausandra macropetala Ducke & 0.59 & 2 & 1 & 37 & 79 \\
\hline 90 & & Pogonophora schomburgkiana Miers ex Benth. & 0.74 & 3 & 1 & 40 & $74,101,17$ \\
\hline 91 & & Sapium marmieri Huber & 0.41 & 2 & 2 & 40 & 55 \\
\hline 92 & & Sapium glandulosum (L.) Morong & 0.47 & 2 & 1 & 40 & 93 \\
\hline
\end{tabular}




\begin{tabular}{|c|c|c|c|c|c|c|c|}
\hline No & Family & Species & $\begin{array}{c}\text { WD } \\
\mathrm{gcm}^{-3}\end{array}$ & ESG & $\mathrm{OCC}$ & $\begin{array}{l}\text { WD } \\
\text { Ref }\end{array}$ & $\begin{array}{l}\text { ESG } \\
\text { Ref }\end{array}$ \\
\hline 93 & FABACEAE CAESALPINIOIDEAE & Apuleia leiocarpa (Vogel) J.F.Macbr. & 0.80 & 3 & 2 & 40 & 31 \\
\hline 94 & & Cassia leiandra Benth. & 0.64 & 2 & 2 & 7 & 43,70 \\
\hline 95 & & Chamaecrista xinguensis (Ducke) H.S.Irwin \& Barneby & 0.90 & 3 & 2 & 16 & \\
\hline 96 & & Crudia glaberrima (Steud.) J.F.Macbr. & 0.79 & 2 & 2 & 40 & 43 \\
\hline 97 & & Dimorphandra pennigera Tul. & 0.75 & 3 & 1 & 40 & \\
\hline 98 & & Hymenaea courbaril L. & 0.81 & 3 & 3 & 40 & 43 \\
\hline 99 & & Hymenaea parvifolia Huber & 0.88 & 3 & 2 & 40 & 43 \\
\hline 100 & & Platymiscium duckei Huber & 0.78 & 3 & 1 & 40 & 90 \\
\hline 101 & & Schizolobium amazonicum Ducke & 0.49 & 1 & 3 & 40 & 43 \\
\hline 102 & & Tachigali paniculata var. alba (Ducke) Dwyer & 0.55 & 1 & 2 & 31 & 43 \\
\hline 103 & & Tachigali myrmecophila (Ducke) Ducke & 0.48 & 3 & 2 & 40 & 43 \\
\hline 104 & & Tachigali paniculata Aubl. & 0.55 & 3 & 3 & 40 & 43 \\
\hline 105 & & Tachigali setifera (Ducke) Zarucchi \& Herend. & 0.67 & 1 & 1 & 40 & 96 \\
\hline 106 & & Tachigali venusta Dwyer & 0.57 & 1 & 1 & 23 & 96 \\
\hline 107 & FABACEAE FABOIDEAE & Andira parvifolia Benth. & 0.92 & 3 & 1 & 40 & 17 \\
\hline 108 & & Bowdichia nitida Benth. & 0.80 & 3 & 2 & 40 & 43 \\
\hline 109 & & Diplotropis martiusii Benth. & 0.63 & 2 & 1 & 40 & 43 \\
\hline 110 & & Diplotropis purpurea (Rich.) Amshoff & 0.78 & 3 & 2 & 40 & 82 \\
\hline 111 & & Diplotropis triloba Gleason & 0.78 & 3 & 1 & 40 & 43 \\
\hline 112 & & Dipteryx odorata (Aubl.) Willd. & 0.92 & 3 & 3 & 40 & 43 \\
\hline 113 & & Dipteryx punctata (S.F.Blake) Amshoff & 0.92 & 3 & 1 & 40 & 89,102 \\
\hline 114 & & Hymenolobium sericeum Ducke & 0.72 & 3 & 1 & 20 & 43 \\
\hline 115 & & Monopteryx inpae W.A.Rodrigues & 0.74 & 3 & 1 & 40 & \\
\hline 116 & & Ormosia discolor Benth. & 0.61 & 3 & 2 & 40 & 56 \\
\hline 117 & & Ormosia flava (Ducke) Rudd & 0.58 & 2 & 2 & 40 & 43 \\
\hline 118 & & Ormosia nobilis var. santaremnensis (Ducke) Rudd & 0.58 & 3 & 2 & 40 & 43 \\
\hline 119 & & Ormosia paraensis Ducke & 0.63 & 3 & 3 & 40 & 43 \\
\hline 120 & & Poecilanthe parviflora Benth. & 0.85 & 3 & 1 & 10,4 & 80 \\
\hline 121 & & Pterocarpus rohrii Vahl & 0.46 & 2 & 1 & 40 & 17 \\
\hline 122 & & Swartzia arborescens (Aubl.) Pittier & 0.83 & 3 & 2 & 40 & 43 \\
\hline 123 & & Swartzia cuspidata Benth. & 0.68 & 3 & 1 & 40 & 67 \\
\hline 124 & & Swartzia laevicarpa Amshoff & 0.61 & 3 & 2 & 40 & 70 \\
\hline 125 & & Swartzia polyphylla DC. & 0.69 & 2 & 2 & 40 & 43 \\
\hline 126 & & Swartzia recurva Poepp. & 0.89 & 3 & 1 & 40 & 95 \\
\hline 127 & & Swartzia schomburgkii Benth. & 0.97 & 3 & 1 & 9 & 67 \\
\hline 128 & & Sweetia nitens (Vogel) Yakovlev & 0.80 & 3 & 2 & 40 & 59,47 \\
\hline 129 & FABACEAE MIMOSOIDEAE & Abarema jupunba (Willd.) Britton \& Killip & 0.59 & 2 & 1 & 40 & 74,43 \\
\hline 130 & & Alexa grandiflora Ducke & 0.66 & 2 & 2 & 40 & 88 \\
\hline 131 & & Dinizia excelsa Ducke & 0.94 & 3 & 1 & 40 & 89 \\
\hline 132 & & Enterolobium maximum Ducke & 0.41 & 1 & 2 & 40 & 14 \\
\hline 133 & & Enterolobium schomburgkii (Benth.) Benth. & 0.72 & 3 & 3 & 40 & 64 \\
\hline 134 & & Inga alba (Sw.) Willd. & 0.59 & 2 & 3 & 40 & $29,74,56$ \\
\hline 135 & & Inga cayennensis Benth. & 0.53 & 2 & 1 & 40 & 74 \\
\hline 136 & & Inga gracilifolia Ducke & 0.66 & 3 & 1 & 38,40 & 43 \\
\hline 137 & & Inga macrophylla Willd. & 0.68 & 3 & 1 & 2 & 43 \\
\hline 138 & & Inga paraensis Ducke & 0.82 & 3 & 1 & 40 & 74 \\
\hline 139 & & Inga pilosula (Rich.) J.F.Macbr. & 0.61 & 2 & 1 & 39 & 64 \\
\hline 140 & & Inga rubiginosa (Rich.) DC. & 0.66 & 3 & 2 & 40 & 43 \\
\hline 141 & & Inga stipularis DC. & 0.53 & 2 & 1 & 40 & 43 \\
\hline
\end{tabular}




\begin{tabular}{|c|c|c|c|c|c|c|c|}
\hline № & Family & Species & $\begin{array}{l}\text { WD } \\
\mathrm{gcm}^{-3}\end{array}$ & ESG & OCC & $\begin{array}{l}\text { WD } \\
\text { Ref }\end{array}$ & $\begin{array}{l}\text { ESG } \\
\text { Ref }\end{array}$ \\
\hline 142 & FABACEAE MIMOSOIDEAE & Inga thibaudiana DC. & 0.66 & 2 & 3 & 20 & $86,74,17$ \\
\hline 143 & & Marmaroxylon racemosum (Ducke) Record & 0.84 & 3 & 2 & 40 & 47 \\
\hline 144 & & Parkia gigantocarpa Ducke & 0.26 & 1 & 2 & 40 & 85 \\
\hline 145 & & Parkia multijuga Benth. & 0.65 & 2 & 3 & 40 & 43 \\
\hline 146 & & Parkia panurensis H.C.Hopkins & 0.65 & 3 & 1 & 27 & 94 \\
\hline 147 & & Parkia pendula (Willd.) Walp. & 0.52 & 2 & 1 & 40 & 43,56 \\
\hline 148 & & Pseudopiptadenia psilostachya (DC.) G.P.Lewis \& M.P.Lima & 0.61 & 3 & 3 & 16 & 43 \\
\hline 149 & & Stryphnodendron pulcherrimum (Willd.) Hochr. & 0.48 & 1 & 3 & 40 & 43 \\
\hline 150 & & Stryphnodendron racemiferum (Ducke) W.A.Rodrigues & 0.75 & 3 & 1 & 40 & \\
\hline 151 & & Stryphnodendron guianense (Aubl.) Benth. & 0.57 & 2 & 1 & 40 & 17 \\
\hline 152 & & Zygia racemosa (Ducke) Barneby \& J.W. Grimes & 0.75 & 3 & 1 & 40 & 17 \\
\hline 153 & GOUPIACEAE & Goupia glabra Aubl. & 0.73 & 2 & 3 & 40 & $43,56,17$ \\
\hline 154 & HUMIRIACEAE & Endopleura uchi (Huber) Cuatrec. & 0.79 & 3 & 2 & 40 & 17 \\
\hline 155 & & Sacoglottis mattogrossensis Malme & 0.77 & 3 & 1 & 40 & 41 \\
\hline 156 & HYPERICACEAE & Vismia cayennensis (Jacq.) Pers. & 0.49 & 1 & 3 & 40 & 74 \\
\hline 157 & & Vismia guianensis (Aubl.) Pers. & 0.48 & 1 & 3 & 40 & 17 \\
\hline 158 & & Vismia japurensis Rchb.f. & 0.56 & 1 & 3 & 19 & 51 \\
\hline 159 & & Vismia gracilis Hieron. & 0.49 & 1 & 1 & 40 & 51 \\
\hline 160 & & Vismia sandwithii Ewan & 0.49 & 1 & 1 & 40 & 51 \\
\hline 161 & ICACINACEAE & Emmotum acuminatum (Benth.) Miers & 0.79 & 2 & 1 & 40 & 43 \\
\hline 162 & & Poraqueiba sericea Tul. & 0.91 & 3 & 1 & 8 & 8 \\
\hline 163 & LACISTEMACEAE & Lacistema aggregatum (P.J.Bergius) Rusby & 0.51 & 1 & 1 & 40 & 74 \\
\hline 164 & & Lacistema grandifolium Schnizl. & 0.52 & 1 & 1 & 40 & 74 \\
\hline 165 & LAMIACAEAE & Vitex triflora Vahl & 0.56 & 2 & 1 & 9 & 31 \\
\hline 166 & LAURACEAE & Aniba burchellii Kosterm. & 0.52 & 3 & 1 & 40 & 43 \\
\hline 167 & & Aniba ferrea Kubitzki & 0.52 & 3 & 1 & $9,38,40$ & 17 \\
\hline 168 & & Aniba panurensis (Meisn.) Mez & 0.61 & 3 & 1 & 40 & 31 \\
\hline 169 & & Aniba paraense Mez. & 0.59 & 3 & 2 & 40 & $43,17,31$ \\
\hline 170 & & Dicypellium manausense W.A.Rodrigues & 0.53 & 3 & 1 & 14 & 53 \\
\hline 171 & & Endlicheria bracteata Mez & 0.50 & 2 & 1 & 40 & 45 \\
\hline 172 & & Licaria chrysophylla (Meisn.) Kosterm. & 0.79 & 2 & 2 & 40 & 56 \\
\hline 173 & & Mezilaurus ita-uba (Meisn.) Taub. ex Mez & 0.74 & 3 & 2 & 40 & 43 \\
\hline 174 & & Mezilaurus lindaviana Schwacke \& Mez & 0.68 & 2 & 2 & 40 & 71 \\
\hline 175 & & Nectandra cuspidata Nees \& Mart. & 0.52 & 3 & 1 & 40 & 43 \\
\hline 176 & & Ocotea baturitensis Vattimo-Gil & 0.56 & 2 & 2 & 40 & \\
\hline 177 & & Ocotea canaliculata (Rich.) Mez & 0.48 & 1 & 2 & 40 & 73 \\
\hline 178 & & Ocotea cujumary Mart. & 0.70 & 3 & 1 & 20 & 43 \\
\hline 179 & & Ocotea glomerata (Nees) Mez & 0.51 & 1 & 2 & 40 & 73 \\
\hline 180 & & Ocotea guianensis Aubl. & 0.53 & 3 & 1 & 40 & 43 \\
\hline 181 & & Sextonia rubra (Mez) van der Werff & 0.55 & 3 & 3 & 40 & 43 \\
\hline 182 & LECYTHIDACEAE & Bertholletia excelsa Bonpl. & 0.64 & 2 & 2 & 40 & 64 \\
\hline 183 & & Corythophora rimosa W.A.Rodrigues & 0.81 & 3 & 1 & 4 & 60 \\
\hline 184 & & Couratariguianensis Aubl. & 0.51 & 3 & 2 & 40 & 43 \\
\hline 185 & & Eschweilera amazonica R.Knuth & 0.90 & 3 & 2 & 40 & 43 \\
\hline 186 & & Eschweilera atropetiolata S.A.Mori & 0.75 & 3 & 1 & 40 & 17 \\
\hline 187 & & Eschweilera bracteosa (Poepp. ex O.Berg) Miers & 0.88 & 3 & 1 & 9 & 56 \\
\hline 188 & & Eschweilera coriacea (DC.) S.A.Mori & 0.85 & 3 & 3 & 40 & 43 \\
\hline 189 & & Eschweilera obversa (O.Berg) Miers & 0.83 & 3 & 2 & 40 & 82,43 \\
\hline 190 & & Eschweilera wachenheimii (Benoist) Sandwith & 0.81 & 3 & 1 & 40 & 82,43 \\
\hline 191 & & Lecythis lurida (Miers) S.A.Mori & 0.86 & 3 & 2 & 40 & 43 \\
\hline 192 & & Lecythis pisonis Cambess. & 0.86 & 3 & 2 & 40 & 43 \\
\hline 193 & & Lecythis prancei S.A.Mori & 0.88 & 3 & 1 & 40 & 43 \\
\hline 194 & & Lecythis zabucajo Aubl. & 0.85 & 3 & 1 & 40 & 43 \\
\hline
\end{tabular}




\begin{tabular}{|c|c|c|c|c|c|c|c|}
\hline No & Family & Species & $\begin{array}{c}\text { WD } \\
\mathrm{gcm}^{-3}\end{array}$ & ESG & OCC & $\begin{array}{l}\text { WD } \\
\text { Ref }\end{array}$ & $\begin{array}{l}\text { ESG } \\
\text { Ref }\end{array}$ \\
\hline 195 & LINACEAE & Roucheria columbiana Hallier f. & 0.77 & 2 & 1 & 40 & 43 \\
\hline 196 & MALPIGHIACEAE & Byrsonima chrysophylla Kunth & 0.69 & 1 & 1 & 38,40 & 43 \\
\hline 197 & & Byrsonima crispa A.Juss. & 0.58 & 3 & 3 & 40 & 43 \\
\hline 198 & & Byrsonima duckeana W.R.Anderson & 0.69 & 3 & 1 & 38,40 & 84,17 \\
\hline 199 & MALVACEAE & Apeiba echinata Gaertn. & 0.36 & 1 & 3 & 31 & 88 \\
\hline 200 & & Eriotheca globosa (Aubl.) A.Robyns & 0.41 & 2 & 3 & 40 & 49 \\
\hline 201 & & Luehea speciosa Willd. & 0.52 & 2 & 2 & 25 & 43 \\
\hline 202 & & Lueheopsis rosea (Ducke) Burret & 0.33 & 2 & 1 & 40 & 56 \\
\hline 203 & & Pachira glabra Pasq. & 0.37 & 2 & 2 & 24 & 42 \\
\hline 204 & & Quararibea ochrocalyx (K.Schum.) Vischer & 0.56 & 2 & 1 & 20 & 88 \\
\hline 205 & & Sterculia frondosa Rich. & 0.47 & 1 & 1 & 40 & \\
\hline 206 & & Theobroma speciosum Willd. ex Spreng. & 0.63 & 2 & 2 & 40 & 43 \\
\hline 207 & & Theobroma sylvestre Aubl. ex Mart. in Buchner & 0.67 & 2 & 1 & 40 & 17 \\
\hline 208 & MELASTOMATACEAE & Bellucia dichotoma Cogn. & 0.54 & 1 & 3 & 17 & 17 \\
\hline 209 & & Bellucia grossularioides (L.) Triana & 0.60 & 1 & 3 & 40 & 51 \\
\hline 210 & & Miconia argyrophylla DC. & 0.54 & 1 & 3 & 23 & 74,17 \\
\hline 211 & & Miconia cuspidata Mart. ex Naudin & 0.87 & 2 & 1 & 5 & 43 \\
\hline 212 & & Miconia eriodonta DC. & 0.63 & 1 & 1 & 2 & 74 \\
\hline 213 & & Miconia poeppigii Triana & 0.60 & 1 & 1 & 40 & 74 \\
\hline 214 & & Miconia regelii Cogn. & 0.60 & 2 & 1 & 38,40 & 68 \\
\hline 215 & & Miconia serialis DC. & 0.60 & 2 & 1 & 38,40 & 43 \\
\hline 216 & & Miconia tetraspermoides Wurdack & 0.60 & 2 & 1 & 38,40 & 31 \\
\hline 217 & & Miconia tomentosa (Rich.) D.Don. & 0.71 & 2 & 1 & 40 & 68 \\
\hline 218 & MELIACEAE & Carapa procera DC. & 0.68 & 2 & 2 & 40 & 74 \\
\hline 219 & & Cedrela fissilis Vell. & 0.47 & 2 & 2 & 40 & 14 \\
\hline 220 & & Cedrela odorata L. & 0.46 & 3 & 2 & 40 & 43 \\
\hline 221 & & Guarea scabra A.Juss. & 0.74 & 3 & 1 & 40 & 43,93 \\
\hline 222 & & Trichilia septentrionalis C.DC. & 0.53 & 3 & 1 & 29 & 43 \\
\hline 223 & MORACEAE & Bagassa guianensis Aubl. & 0.71 & 1 & 2 & 40 & 74,100 \\
\hline 224 & & Brosimum rubescens Taub. & 0.83 & 3 & 1 & 40 & 17 \\
\hline 225 & & Brosimum acutifolium Huber & 0.64 & 2 & 2 & 40 & 43 \\
\hline 226 & & Brosimum guianense (Aubl.) Huber ex Ducke & 0.84 & 2 & 2 & 40 & 69,29 \\
\hline 227 & & Brosimum lactescens (S.Moore) C.C.Berg & 0.66 & 2 & 2 & 40 & 29,75 \\
\hline 228 & & Brosimum parinarioides Ducke & 0.63 & 2 & 3 & 40 & 69 \\
\hline 229 & & Clarisia racemosa Ruiz \& Pav. & 0.59 & 3 & 3 & 40 & 31 \\
\hline 230 & & Ficus gomelleira Kunth \& C.D.Bouché & 0.39 & 2 & 1 & 22 & 31 \\
\hline 231 & & Ficus nymphaeifolia Mill. & 0.59 & 1 & 3 & $38,40,4$ & 74 \\
\hline 232 & & Ficus sp. & 0.41 & 2 & 3 & 40 & 75 \\
\hline 233 & & Helicostylis scabra (J.F.Macbr.) C.C.Berg & 0.74 & 3 & 1 & 40 & 31 \\
\hline 234 & & Helicostylis tomentosa (Poepp. \& Endl.) J.F.Macbr. & 0.63 & 2 & 1 & 40 & 43 \\
\hline 235 & & Maquira sclerophylla (Ducke) C.C.Berg & 0.51 & 1 & 3 & 40 & 43 \\
\hline 236 & & Naucleopsis caloneura (Huber) Ducke & 0.55 & 2 & 1 & 20,37 & 56 \\
\hline 237 & & Perebea mollis (Poepp. \& Endl.) Huber & 0.37 & 2 & 2 & 40 & 82 \\
\hline 238 & MYRISTICACEAE & Iryanthera grandis Ducke & 0.63 & 3 & 2 & 40 & 31 \\
\hline 239 & & Iryanthera juruensis Warb. & 0.63 & 2 & 1 & 40 & 69,17 \\
\hline 240 & & Osteophloeum platyspermum (Spruce ex A.DC.) Warb. & 0.47 & 3 & 1 & 40 & 43 \\
\hline 241 & & Virola multinervia Ducke & 0.45 & 2 & 1 & 15 & 15 \\
\hline 242 & & Virola michelii Heckel & 0.47 & 2 & 3 & 40 & 17 \\
\hline
\end{tabular}




\begin{tabular}{|c|c|c|c|c|c|c|c|}
\hline No & Family & Species & $\begin{array}{c}\text { WD } \\
\mathrm{gcm}^{-3}\end{array}$ & ESG & OCC & $\begin{array}{l}\text { WD } \\
\text { Ref }\end{array}$ & $\begin{array}{l}\text { ESG } \\
\text { Ref }\end{array}$ \\
\hline 243 & MYRTACEAE & Calyptranthes crebra McVaugh & 0.78 & 2 & 1 & 40 & 56 \\
\hline 244 & & Eugenia patrisii Vahl & 0.83 & 3 & 1 & 40 & 70 \\
\hline 245 & & Eugenia sp. & 0.76 & 3 & 3 & 40 & 17 \\
\hline 246 & & Myrcia fallax (Rich.) DC. & 0.82 & 3 & 1 & 40 & 74 \\
\hline 247 & & Myrcia guianensis (Aubl.) DC. & 0.74 & 2 & 1 & 1 & 61 \\
\hline 248 & & Myrcia magnoliifolia DC. & 0.77 & 3 & 1 & 40 & \\
\hline 249 & & Myrcia paivae O.Berg & 0.77 & 2 & 2 & 40 & 55 \\
\hline 250 & & Myrcia sylvatica (G.Mey.) DC. & 0.76 & 3 & 1 & 6 & 31 \\
\hline 251 & & Myrciaria floribunda (H.West ex Willd.) O.Berg & 0.79 & 3 & 3 & 40 & 88 \\
\hline 252 & NA & Dead tree & 0.34 & 5 & 3 & 3 & \\
\hline 253 & NYCTAGINACEAE & Neea madeirana Standl. & 0.55 & 2 & 1 & 40 & 67 \\
\hline 254 & & Neea oppositifolia Ruiz \& Pav. & 0.89 & 1 & 2 & 40 & 43,75 \\
\hline 255 & OLACACEAE & Chaunochiton kappleri (Sagot ex Engl.) Ducke & 0.52 & 2 & 1 & 40 & 43 \\
\hline 256 & & Dulacia guianensis (Engl.) Kuntze & 0.57 & 3 & 1 & 40 & 49 \\
\hline 257 & & Minquartia guianensis Aubl. & 0.80 & 3 & 1 & 40 & 43 \\
\hline 258 & OPILIACEAE & Agonandra silvatica Ducke & 0.83 & 3 & 1 & 40 & 62 \\
\hline 259 & PERACEAE & Pera glabrata (Schott) Poepp. ex Baill. & 0.67 & 1 & 1 & 40 & 43 \\
\hline 260 & PHYLLANTHACEAE & Margaritaria nobilis L.f. & 0.48 & 2 & 2 & 40 & 72 \\
\hline 261 & POLYGONACEAE & Coccoloba latifolia Poir. & 0.58 & 1 & 2 & 40 & 43 \\
\hline 262 & PROTEACEAE & Roupala montana Aubl. & 0.73 & 3 & 1 & 40 & 44,98 \\
\hline 263 & QUIINACEAE & Lacunaria jenmanii (Oliv.) Ducke & 0.92 & 3 & 1 & 38,40 & 56 \\
\hline 264 & & Touroulia guianensis Aubl. & 0.76 & 3 & 1 & 40 & \\
\hline 265 & RUBIACEAE & Capirona decorticans Spruce & 0.59 & 2 & 2 & 40 & 96 \\
\hline 266 & & Chimarrhis barbata (Ducke) Bremek. & 0.71 & 2 & 1 & 40 & 62 \\
\hline 267 & & Chimarrhis turbinata DC. & 0.72 & 2 & 2 & 40 & 74 \\
\hline 268 & & Coussarea ampla Müll.Arg. & 0.48 & 2 & 1 & 40 & 83 \\
\hline 269 & & Duroia longiflora Ducke & 0.81 & 3 & 1 & 38 & 82,70 \\
\hline 270 & & Genipa americana L. & 0.62 & 1 & 2 & 40 & 43 \\
\hline 271 & & Isertia hypoleuca Benth. & 0.61 & 1 & 1 & 40 & 50 \\
\hline 272 & & Palicourea corymbifera (Müll.Arg.) Standl. & 0.66 & 1 & 1 & 38,40 & 92 \\
\hline 273 & & Palicourea guianensis Aubl. & 0.54 & 1 & 1 & 40 & 74 \\
\hline 274 & & Fagara sp. & 0.56 & 2 & 2 & 40 & 66 \\
\hline 275 & & Zanthoxylum rhoifolium Lam. & 0.57 & 2 & 3 & 40 & $43,56,17$ \\
\hline 276 & SALICACEAE & Casearia grandiflora Cambess. & 0.77 & 2 & 1 & 40 & 31 \\
\hline 277 & & Casearia javitensis Kunth & 0.75 & 2 & 2 & 40 & 74 \\
\hline 278 & & Casearia pitumba Sleumer & 0.73 & 2 & 1 & 40 & 74,63 \\
\hline 279 & & Casearia spruceana Benth. ex Eichler & 0.68 & 2 & 2 & 40 & 75 \\
\hline 280 & & Casearia ulmifolia Vahl ex Vent. & 0.68 & 2 & 1 & 33,40 & $74,63,75$ \\
\hline 281 & & Laetia procera (Poepp.) Eichl. & 0.63 & 2 & 3 & 40 & $74,51,17$ \\
\hline 282 & & Ryania speciosa Vahl & 0.49 & 1 & 1 & 36 & \\
\hline 283 & SAPINDACEAE & Cupania hispida Radlk. & 0.64 & 1 & 1 & 40 & 43 \\
\hline 284 & & Matayba arborescens (Aubl.) Radlk. & 0.70 & 1 & 1 & 40 & 43 \\
\hline 285 & & Talisia carinata Radlk. & 0.86 & 3 & 2 & 30 & \\
\hline 286 & & Talisia longifolia (Benth.) Radlk. & 0.93 & 3 & 2 & 6 & 81 \\
\hline 287 & & Talisia praealta Radlk. & 1.05 & 3 & 1 & 38 & \\
\hline
\end{tabular}




\begin{tabular}{|c|c|c|c|c|c|c|c|}
\hline No & Family & Species & $\begin{array}{l}\text { WD } \\
\mathrm{gcm}^{-3}\end{array}$ & ESG & OCC & $\begin{array}{l}\text { WD } \\
\text { Ref }\end{array}$ & $\begin{array}{l}\text { ESG } \\
\text { Ref }\end{array}$ \\
\hline 288 & SAPOTACEAE & Manilkara bidentata (A.DC.) A.Chev. & 0.87 & 3 & 1 & 40 & 43 \\
\hline 289 & & Manilkara huberi (Ducke) Standl. & 0.92 & 3 & 2 & 40 & 43 \\
\hline 290 & & Micropholis casiquiarensis Aubrév. & 0.71 & 3 & 1 & 40 & \\
\hline 291 & & Micropholis venulosa (Mart. \& Eichler ex Miq.) Pierre & 0.67 & 3 & 1 & 40 & 43 \\
\hline 292 & & Pouteria bilocularis (H.J.P.Winkl.) Baehni & 0.71 & 3 & 2 & 40 & 43 \\
\hline 293 & & Pouteria gongrijpii Eyma & 0.80 & 3 & 2 & 40 & 43 \\
\hline 294 & & Pouteria guianensis Aubl. & 0.93 & 3 & 1 & 40 & 43 \\
\hline 295 & & Pouteria macrophylla (Lam.) Eyma & 0.74 & 3 & 2 & 40 & 43 \\
\hline 296 & & Pouteria oblanceolata Pires & 0.79 & 3 & 1 & 40 & 17 \\
\hline 297 & & Pouteria opposita (Ducke) T.D.Penn. & 0.65 & 3 & 1 & 9 & 43 \\
\hline 298 & & Pouteria petiolata T.D.Penn. & 0.68 & 3 & 1 & 20 & 91 \\
\hline 299 & & Pouteria platyphylla (A.C.Sm.) Baehni & 0.80 & 3 & 1 & 28 & 43,70 \\
\hline 300 & & Pouteria sp. & 0.78 & 3 & 2 & 40 & 43,70 \\
\hline 301 & & Pouteria torta (Mart.) Radlk. & 0.77 & 2 & 2 & 40 & 87 \\
\hline 302 & & Pouteria manaosensis Aubrév. \& Pellegr. & 0.64 & 3 & 1 & 15 & 17 \\
\hline 303 & SIMAROUBACEAE & Simaba cedron Planch. & 0.47 & 2 & 1 & 40 & 43 \\
\hline 304 & & Simaba polyphylla (Cavalcante) W.W. Thomas & 0.45 & 2 & 1 & 38 & 54 \\
\hline 305 & & Simarouba amara Aubl. & 0.38 & 2 & 1 & 40 & $74,17,56$ \\
\hline 306 & SIPARUNACEAE & Siparuna guianensis Aubl. & 0.56 & 2 & 1 & 11 & 17 \\
\hline 307 & STRELITZIACEAE & Phenakospermum guyannense (A.Rich.) Endl. & 0.17 & 1 & 1 & 32 & 58 \\
\hline 308 & ULMACEAE & Ampelocera edentula Kuhlm. & 0.70 & 2 & 1 & 40 & 43 \\
\hline 309 & URTICACEAE & Cecropia palmata Willd. & 0.39 & 1 & 2 & 26 & 43 \\
\hline 310 & & Cecropia purpurascens C.C.Berg & 0.31 & 1 & 1 & 17 & 51,17 \\
\hline 311 & & Cecropia sciadophylla Mart. & 0.39 & 1 & 3 & 40 & 17 \\
\hline 312 & & Pourouma guianensis Aubl. & 0.38 & 1 & 3 & 40 & 74,43 \\
\hline 313 & & Pourouma villosa Trécul & 0.34 & 1 & 1 & 40 & 74,43 \\
\hline 314 & VIOLACEAE & Rinorea guianensis Aubl. & 0.78 & 2 & 3 & 40 & 17 \\
\hline 315 & & Rinorea racemosa (Mart.) Kuntze & 0.68 & 2 & 1 & 40 & 17 \\
\hline 316 & & Rinorea pubiflora (Benth.) Sprague \& Sandwith & 0.75 & 3 & 2 & 40 & 55 \\
\hline 317 & VOCHYSIACEAE & Erisma bicolor Ducke & 0.70 & 3 & 1 & 27 & 75 \\
\hline 318 & & Qualea paraensis Ducke & 0.69 & 3 & 1 & 40 & 43 \\
\hline 319 & & Qualea albiflora Warm. & 0.57 & 3 & 1 & 40 & 43 \\
\hline 320 & & Vochysia vismiifolia Spruce ex Warm. & 0.75 & 3 & 1 & 27 & 43 \\
\hline 321 & & Unknown & 0.62 & 5 & 2 & & \\
\hline 322 & & Unknown & 0.62 & 5 & 2 & & \\
\hline 323 & & Unknown & 0.62 & 5 & 2 & & \\
\hline
\end{tabular}

References

[1] Batalha, M.A.; Silva, I.A.; Cianciaruso, M.V.; França, H.; de Carvalho, G.H. 2011. Phylogeny, traits, environment, and space in Cerrado plant communities at Emas National Park (Brazil). Flora: Morphology, Distribution, Functional Ecology of Plants, 206: 949-956.

[2] Block, A. 2004. Göttinger Mähhäcksler Tritucap und Forstmulcher- Nicht brennende Flächenvorbereitung am Beispiel der Zona Bragantina, Nord-Ost-Amazonien, Brasilien. Georg-August-Universität, Göttingen, 219p.

[3] Chao, K.-J; Phillips, O.L.; Baker, T.R. 2008. Wood density and stocks of coarse woody debris in a northwestern Amazonian landscape. Canadian Journal of Forest Research, 38: 795-805.

[4] Chave, J.; Muller-Landau, H.C.; Baker, T.R.; Easdale, T.A.; Steege, H. ter; Webb, C.O. 2006. Regional and phylogenetic variation of wood density across 2456 neotropical tree species. Ecological Applications, 16: 2356-2367.

[5] Diniz, B.M. 2009. Relações hídricas e morfo-anatomia do caule em pares congenéricos do cerrado e mata de galeria: um estudo comparativo. Master's thesis. Universidade de Brasília, Brasília. 97p.

[6] Ducey, M.J.; Zarin, D.J.; Vasconcelos, S.S.; Araújo, M.M. 2009. Biomass equations for forest regrowth in the eastern Amazon using randomized branch sampling Acta Amazonica, 39: 349-360. 
[7] Encyclopedia of Life. 2016. (http://www.eol.org). Accessed on 15/01/2016.

[8] Falcão, M. de A.; LLeras, E. 1980. Aspectos fenológicos, ecológicos e de produtividade do umari (Poraqueiba sericea Tulasne). Acta Amazonica, $10: 445-462$. [9] Fearnside, P.M. 1996. Wood density for estimating forest biomass in Brazilian Amazonia. National Institute for Research in the Amazon - INPA, Manaus, Brazil, 80p.

[10] Ferez, A.P.C. 2010. Effect of silvicultural practices on the initial rates of carbon sequestration in Atlantic forest restorations. Master's thesis. Universidade de São Paulo, São Paulo, 106p.

[11] Gaspar, R.D.O.; Castro, R.V.O.; Peloso, R.V. Del; Souza, F.C. de; Martins, S.V. 2014. Análise fitossociológica e do estoque de carbono no estrato arbóreo de um fragmento de Floresta Estacional Semidecidual. Ciência Florestal, 24: 313-324.

[12] Gehring, C.; Zelarayán, M.L.C.; Almeida, R.B.; Moraes, F.H.R. 2011. Allometry of the babassu palm growing on a slash- and-burn agroecosystem of the eastern periphery of Amazonia. Acta Amazonica, 41:127-134.

[13] Goodman, R.C.; Phillips, O.L.; del Castillo Torres, D.; Freitas, L.; Cortese, S.T.; Monteagudo, A.; Baker, T.R. 2013. Amazon palm biomass and allometry. Forest Ecology and Management, 310: 994-1004

[14] Herrero-Jáuregui, C.; García-Fernández, C.; Sist, P.L.J; Casado, M.A. 2009. Conflict of use for multi-purpose tree species in the state of Pará, eastern Amazonia, Brazil. Biodiversity and Conservation, 18: 1019-1044.

[15] Holm, J.A.; Chambers, J.Q.; Collins, W.D.; Higuchi, N. 2014. Forest response to increased disturbance in the central Amazon and comparison to western Amazonian forests. Biogeosciences, 11:5773-5794.

[16] Condé, T.M.; Tonini, H. 2013. Fitossociologia de uma Floresta Ombrófila Densa na Amazônia Setentrional, Roraima, Brasil. Acta Amazonica, 43: 247-260.

[17] Magnabosco Marra, D.; Higuchi, N.; Trumbore, S.E.; Ribeiro, G.H.P.M.; dos Santos, J.; Carneiro, V.M.C.; et al. 2016. Predicting biomass of hyperdiverse and structurally complex central Amazonian forests \&amp;ndash; a virtual approach using extensive field data. Biogeosciences, 13: 1553-1570.

[18] Miguel, E.P. 2014. Caracterização da flora e da produção em volume, biomassa e carbono da vegetação arbórea em área de cerradão no estado do Tocantins. Doctoral thesis. Universidade de Brasília, Brasília, 88p.

[19] Nelson, B.W.; Mesquita, R.; Pereira, J.L.; Garcia Aquino de Souza, S.; Teixeira Batista, G.; Bovino Couto, L. 1999. Allometric regressions for improved estimate of secondary forest biomass in the central Amazon. Forest Ecology and Management, 117: 149-167.

[20] Nogueira, E.M.; Nelson, B.W.; Fearnside, P.M.; França, M.B.; Oliveira, Á.C.A. de. 2008. Tree height in Brazil's "arc of deforestation": Shorter trees in south and southwest Amazonia imply lower biomass. Forest Ecology and Management, 255: 2963-2972.

[21] Nogueira, E.M.; Nelson, B.W.; Fearnside, P.M. 2005. Wood density in dense forest in central Amazonia, Brazil. Forest Ecology and Management, $208: 261-286$.

[22] Salomão, R. de P. 1994. Estimativas de biomassa e avaliação do estoque de carbono da vegetação de florestas primárias e secundárias de diversas idades (capoeiras) na Amazônia oriental, município de Peixe-boi, Pará. Master's thesis. Universidade Federal do Pará, Belém, 59p.

[23] Oliveira, C.L. de. 2010. Estimativas da dinâmica de carbono na biomassa lenhosa de terra-firme na Reserva de Desenvolvimento Sustentável Amanã por métodos dendrocronológicos. Master's thesis. Instituto Nacional de Pesquisas da Amazônia (INPA), Manaus, 53p.

[24] Oliveira, G.M.V. 2014. Densidade da madeira em Minas Gerais : amostragem, espacialização e relação com variáveis ambientais. Doctoral thesis. Universidade Federal de Lavras, Lavras. 125p.

[25] Ordoñez Diaz, J.A.B.; Galicia Naranjo, A.; Venegas Mancera, N.J.; Hernández Tejeda, T.; Ordóñez Díaz, M. de J.: Dávalos-Sotelo, R. 2015. Densidad de las maderas mexicanas. Madera y Bosques, 21: 77-126.

[26] Paula, J.E. 2003. Caracterização anatômica da madeira de sete espécies da amazônia com vistas à produção de energia e papel. Acta Amazonica, 33: $243-262$.

[27] Paula, J.E. Alves, J.L. 1997. Madeiras nativas: anatomia, dendrologia, dendrometria, produção, uso. Fundação Mokiti Okada, Brasília. 541 p.

[28] Amaral, D.D.; Viera, I.C.G.; Salomão, R.P.; Almeida, S.S. de.; Jardim, M.A.G. 2009. Checklist da flora arbórea de remanescentes florestais da região metropolitana de Belém, Pará, Brasil. Boletim do Museu Paraense Emilio Goeldi, Ciências Naturais, 4: 231-289.

[29] Plourde, B.T.; Boukili, V.K.; Chazdon, R.L. 2015. Radial changes in wood specific gravity of tropical trees: Inter- and intraspecific variation during secondary succession. Functional Ecology, 29:111-120.

[30] Puig, C.J. 2005. Carbon sequestration potential of land-cover types in the agricultural landscape of eastern Amazonia, Brazil. In: Vlek, P.L.G. (ed.) Ecology and Development Series, Cuvillier Ed., Göttingen, 168p.

[31] Salomão, R. de P. 1994. Estimativas de biomassa e avaliação do estoque de carbono da vegetação de florestas primárias e secundárias de diversas idades (capoeiras) na Amazônia oriental, município de Peixe-boi, Pará. Master's thesis. Universidade Federal do Pará, Belém, 59p.

[32] Junior, H.S.; Pimentel, L.L. 2000. Viabilidade do aproveitamento de resíduos de fibras vegetais para fins de obtenção de material de construção. Revista Brasileira de Engenharia Agricola e Ambiental, 4: 103-110.

[33] Souza, A.L. De; Boina, A.; Soares, C.P.B.; Vital, B.R.; Gaspar, R.D.O.; Lana, J.M. De. 2012. Estrutura fitossociológica, estoques de volume, biomassa, carbono e dióxido de carbono em Floresta Estacional Semidecidual. Revista Árvore, 36: 169-179.

[34] Trianoski, R.; I wakiri, S.; Nascimento, C.C.; Bila, N.F. 2015. Painéis aglomerados produzidos com quatro espécies de madeiras tropicais da Amazônia. Scientia Forestalis, 43: 445-452.

[35] UNFCCC, 1992. Local data for wood density. Report \# 16a (https://cdm.unfccc.int/). Accessed on 17/03/2016.

[36] van Breugel, M.; Ransijn, J.; Craven, D.; Bongers, F.; Hall, J.S. 2011. Estimating carbon stock in secondary forests: Decisions and uncertainties associated with allometric biomass models. Forest Ecology and Management, 262: 1648-1657.

[37] Vaz, M.C. 2011. Diversidade de estratégias ecológicas das espécies de árvore dominantes de uma floresta de terra firme da Amazônia Central. Master's thesis. Universidade de São Paulo, São Paulo, 115p.

[38] Wagner, F. 2011. La réponse des forêts tropicales humides aux variations climatiques Évolution de la structure et de la dynamique des peuplements forestiers guyanais. Doctoral thesis. Université des Antilles et de la Guyane, Guyane, 260p.

[39] Wittman, F.; Schöngart, J; Parolin, P.; Worbes, M.; Piedade, M.T.; Junk, W.J. 2006. Wood specific gravity of trees in Amazonian white-water forests in relation to flooding. IAWA Journal, 27: 255-266.

[40] Zanne, A.E.; Lopez-Gonzalez, G.; Coomes, D.A.A.; Ilic, J.; Jansen, S.; Lewis, S.L.S.L.; et al. 2009. Global wood density database. Dryad, 235 (February): 33.

[41] Abreu, T.A.L.; Pinto, J.R.R.; Mews, H.A. 2014. Variações na riqueza e na diversidade de espécies arbustivas e arbóreas no período de 14 anos em uma Floresta de Vale, Mato Grosso, Brasil. Rodriguésia, 65: 73-88.

[42] Almeida, R.F. de; De Sordi, S.J.; Garcia, R.J.F. 2010. Aspectos Florísticos, Históricos e Ecológicos do Componente Arbóreo do Parque da Independência, São Paulo, SP. REVSBAU, 5: 18-41.

[43] Amaral, D.D.; Viera, I.C.G.; Salomão, R.P.; Almeida, S.S. de.; Jardim, M.A.G. 2009. Checklist da flora arbórea de remanescentes florestais da região metropolitana de Belém, Pará, Brasil. Boletim do Museu Paraense Emilio Goeldi, Ciências Naturais, 4: 231-289.

[44] da Silva, A.C.; Higuchi, P.; Negrini, M.; Grudtner, A.; Zech, D.F. 2013. Caracterização fitossociológica e fitogeográfica de um trecho de floresta ciliar em Alfredo Wagner, SC, como subsídio para restauração ecológica. Ciencia Florestal, 23: 579-593.

[45] Andrade, T.M. 2012. Regeneração de Espécies Arbóreas em Clareiras Antropizadas na Reserva de Desenvolvimento Sustentável Mamirauá- RDSM, Amazônia Central. Doctoral thesis. Instituto Nacional de Pesquisas da Amazônia, Manaus, 96p.

[46] Araújo, L.R.; Silveira, V.R. 2013. Projeto de plantio compensatório - Rodovia BR-230/PA. Marabá, Pará. DNIT, Marabá, Pará, 47p. 
[47] Araújo, G.C. 2010. Radiação e liteira em ecossistemas de florestas com ocorrência de Attalea maripa (Aubl.) Mart.: estudo de caso na Amazônia Oriental. Master's thesis. Universidade Federal Rural da Amazônia, Belém. 70p.

[48] Asmus, G.F. 2008. Influência da topografia na disponibilidade de nitrogênio mineral e na assimilação de nitrato por árvores da floresta de terra firme da Amazônia central. Master's thesis. Instituto Nacional de Pesquisas da Amazônia, Manaus, 43p.

[49] Azevedo, C.P. De; Sanquetta, C.R.; Silva, J.N.M.; Machado, S. do A. 2008. Efeito da exploração de madeira e dos tratamentos silviculturais no agrupamento ecológico de espécies. Floresta, 38: 53-69.

[50] Bentos, T.V. 2006. Estratégias reprodutivas de espécies pioneiras na Amazônia Central: Fenologia e sucesso no estabelecimento de plantas. Master's thesis. Instituto Nacional de Pesquisas da Amazônia, Manaus, 76p.

[51] Bentos, T.V. 2013. Potencial reprodutivo e regenerativo de espécies arbóreas em florestas secundárias na Amazônia Central. Doctoral thesis. Instituto Nacional de Pesquisas da Amazônia, Manaus, 92p.

[52] Boshier, D.H.; Lamb, A.T. 1997. Cordia alliadora: Genetics and Tree Improvement. In: Boshier, D.H.; Lamb, A.T. (eds.) Tropical Forest Papers, No 36, Oxford Forestry Institute, Oxford, 96p.

[53] Capossoli, D.J. 2013. Restauração ecológica: ligando prática e teoria. Doctoral thesis. Instituto de Pesquisas Jardim Botânico do Rio de Janeiro, Rio de Janeiro, 231p.

[54] Chevarría, M.G. 2011. Recuperación del bosque húmedo tropical 19 años después de la cosecha bajo cuatro sistemas de manejo forestal, en la Península de Osa, Costa Rica. Bachelor dissertation. Instituto Tecnológico de Costa Rica, Cartago, Costa Rica, 128p.

[55] Rodrigues Coelho, R. de F.; Miranda, I. de S.; Mitja, D. 2013. Conservation of the forests at Benfica Settlement Project in Southeastern Amazon. Ciencia Florestal, 23: 1-17.

[56] Condé, T.M.; Tonini, H. 2013. Fitossociologia de uma Floresta Ombrófila Densa na Amazônia Setentrional, Roraima, Brasil. Acta Amazonica, 43: $247-260$.

[57] Coomes, D.A.; Grubb, P.J. 1998. Responses of juvenile trees to above- and belowground competition in nutrient-starved Amazonian Rain Forest. Ecology, 79: 768-782.

[58] Costa, F.R.C.; Espinelli, F.P.; Figueiredo, F.O.G. 2010. Guia de Zingiberales dos sítios PPBio na Amazônia Ocidental Brasileira. Áttema Design Editorial, Manaus, 290p.

[59] Espírito-Santo, F.D.B. 2003. Caracterização e mapeamento da vegetação da região da Floresta Nacional do Tapajós através de dados óticos, radar e inventários florestais. Master"s thesis. Instituto Nacional de Pesquisas Espaciais, São josé dos Campos, São Paulo, 277p.

[60] Ferraz, I.D.K.; Leal Filho, N.; Imakawa, A.M.; Varela, V.P.; Piña-Rodrigues, F.C.M. 2004. Características básicas para um agrupamento ecológico preliminar de espécies madeireiras da floresta de terra firme da Amazônia Central. Acta Amazonica, 34: 621-633.

[61] Ferreira, P.I.; Gomes, J.P.; Batista, F.; Bernardi, A.P.; Clóvis, N.; Lopes, R.; Mantovani, A. 2013. Espécies potenciais para recuperação de áreas de preservação permanente no Planalto Catarinense. Floram: Floresta e Ambiente, 20: 173-182.

[62] Flora do Brasil. 2020 em construção. Jardim Botânico do Rio de Janeiro. (http://floradobrasil.jbrj.gov.br). Accessed on 16/02/2016.

[63] Gomide, G.L.A. 2003. Dinâmica sucessional de florestas neotropicais secundárias: estudos de caso na Amazônia Brasileira e na Costa Rica. Doctoral thesis. Universidade Federal do Paraná, Curitiba, 173p.

[64] Gonçalves, I.K. 2012. Diversidade e distribuição geográfica de Leguminosae Adans. na Amazônia Meridional, Mato Grosso, Brasi. Master's thesis. Universidade Federal de Viçosa, Viçosa, 75p.

[65] Guimarães, R. de P.M. 2013. Avaliação da regeneração natural de Tetragastris altissima (Aubl.) Swart em clareiras abertas em florestas exploradas seletivamente. Master's thesis. Universidade Federal Rural da Amazônia, Belém, 100p.

[66] Holz, S.; Placci, G.; Quintana, R.D. 2009. Effects of history of use on secondary forest regeneration in the upper Parana Atlantic Forest (Misiones, Argentina). Forest Ecology and Management, 258: 1629-1642.

[67] IPAM, Instituto de Proteção Ambiental do Estado do Amazonas. 2012. Estudo prévio de impacto ambiental na cidade universitária, município de Iranduba - AM. IPAM, Manaus, 892p.

[68] Laurance, W.F.; Ferreira, L. V.; Rankin-de Merona, J.M.; Laurance, S.G. 1998. Rain forest fragmentation and the dynamics of Amazonian tree communities. Ecology, 79: 2032-2040.

[69] Laurance, W.F.; Nascimento, H.E..; Laurance, S.G.; Condit, R.; D’Angelo, S.; Andrade, A. 2004. Inferred longevity of Amazonian rainforest trees based on a longterm demographic study. Forest Ecology and Management, 190: 131-143.

[70] Lima, R.B.D.A.; Silva, J.A.A. Da; Marangon, L.C.; Ferreira, R.L.C.; Silva, R.K.S. Da. 2011. Sucessão ecológica de um trecho de Floresta Ombrófila Densa de Terras Baixas, Carauari, Amazonas. Pesquisa Florestal Brasileira, 2011: 161-172.

[71] Lopes, J. do C.A.; Schwartz, G.; Silva, K.R. 2009. Crescimento de mudas de Itaúba (Mezilaurus lindaviana Schwacke \& Mez) plantadas em clareiras de exploração nas áreas de manejo da Orsa Florestal SIA, em Monte Dourado, Distrito de Almeirim-PA. Embrapa, Belém, 9p.

[72] Lopes, S.D.F.; Vale, V.S.; Prado Júnior, J.A.; De Oliveira, A.P.; Schiavini, I. 2012. Estrutura e grupos ecológicos de um remanescente florestal urbano com histórico de perturbação recente em Uberlândia, MG. Biotemas, 25: 91-102.

[73] Marangon, G.P.; Cruz, A.F.; Barbosa, W.B.; Loureiro, G.H.; de Holanda, A.C. 2010. Dispersão de sementes de uma comunidade arbórea em um remanescente de Mata Atlântica, município de Bonito, PE. Revista Verde de Agroecologia e Desenvolvimento Sustentável, 5: 80-87.

[74] Molino, J.-F. 2001. Tree diversity in tropical rain forests: a validation of the intermediate disturbance hypothesis. Science, $294: 1702-1704$.

[75] Nemer, T.C. 2014. Dinâmica da vegetação de Floresta Tropical de Terra Firme influenciada por clareiras de origem antrópica, Moju, Pará, Brasi. Doctoral thesis. Universidade de Brasília, Brasília, 97p.

[76] Nunes, J.A.; Schaefer, C.E.G.R.; Ferreira Júnior, W.G.; Neri, A. V.; Correa, G.R.; Enright, N.J. 2015. Soil-vegetation relationships on a banded ironstone "island”, Carajás Plateau, Brazilian Eastern Amazonia. Anais da Academia Brasileira de Ciências, 87: 2097-2110.

[77] Oliveira-Filho, A.T. de; Van den Berg, E.; Machado, E.L.M.; Pifano, D.S.; Santos, R.M. dos; Valente, A.S.M.; et al. 2008. Espécies de ocorrência exclusiva do Domínio do Cerrado. In: Oliveira-Filho, A.T. de; Scolfor, J.R. (eds.), Inventário Florestal de Minas Gerais: Espécies Arbóreas Da Flora Nativa. UFLA, Lavras, p.157-208.

[78] Oliveira, L.C. De. 2005. Efeito da exploração da madeira e de diferentes intensidades de desbastes sobre a dinâmica da vegetação de uma área de 136 ha na Floresta Nacional do Tapajós. Doctoral thesis. Universidade de São Paulo, Piracicaba, 196p.

[79] Oliveira, A.J.F. 2005. Fatores que influenciam no desenvolvimento de Cupiúba (Goupia glabra Aubl.) em capoeiras artificiais de uma Floresta de Terra Firme na Amazônia Central - Amazonas, Brasil. Master's thesis. Instituto Nacional de Pesquisas da Amazônia, Manaus, 75p.

[80] Padovani, V.C.R. 2013. Uso de composto orgânico de lodo de esgoto para adubação de plantio de essências florestais. Doctoral thesis. Universidade Federal de Campinas, Campinas, 156p.

[81] Phillips, P.D.; De Azevedo, C.P.; Degen, B.; Thompson, I.S.; Silva, J.N.M.; Van Gardingen, P.R. 2004. An individual-based spatially explicit simulation model for strategic forest management planning in the Eastern Amazon. Ecological Modelling, 173: 335-354.

[82] Pinheiro, K.A.O.; Carvalho, J.O.P. de; Quanz, B.; Francez, L.M. de B.; Schwartz, G. 2007. Fitossociologia de uma área de preservação permanente no leste da Amazônia: indicação de espécies para recuperação de áreas alteradas. FLORESTA, 37: 175-187.

[83] Prado Júnior, J.A.; Lopes, S.D.F.; Schiavini, l.; do Vale, V.S.; Oliveira, A.P. De; Gusson, A.E.; et al. 2012. Fitossociologia, caracterização sucessional e síndromes de dispersão da comunidade arbórea de remanescente urbano de Floresta Estacional Semidecidual em Monte Carmelo, Minas Gerais. Rodriguésia, 63: 489-499.

[84] Prata, S.S. 2007. Sucessão ecológica da vegetação arbórea em florestas secundárias do nordeste do estado do Pará. Master's thesis. Universidade Federal Rural da Amazônia, 77p.

[85] Ribeiro, J.W.F.; Oliveira, A.K.M. De; Contreiras Rodrigues, A.P.D.; Rondon, E.V. 2015. Germination and morphology of seeds and seedlings of Parkia 
ACTA

AMAZONICA

CASSOL et al. Improved tree height estimation in the Amazon

gigantocarpa Fabaceae: Mimosoideae. Floresta, 45: 303.

[86] Rolim, S.G.; Do Couto, H.T.Z.; De Jesus, R.M. 1999. Mortalidade e recrutamento de árvores na Floresta atlântica em Linhares (ES). Scientia Forestalis/Forest Sciences 55: 49-69.

[87] Sá, D.; Lopes, S. de F.; Prado Júnior, J.A.; Schiavini, l.; Vale, V.S.; Oliveira, A.P.; Dias Neto, O.C.; Gusson, A.E. 2012. Estrutura e grupos ecológicos de um fragmento de floresta estacional semidecidual no Triângulo Mineiro, Brasil. Caminhos de gografia, 13: 89-101.

[88] Salomão, R. de P.; Rosa, N.A.; Nepstad, D.C.; Bakk, A. 1995. Estrutura diamétrica e breve caracterização ecológica econômica de 108 espécies arbóreas da floresta amazônica brasileira - I. Interciência, 20: 20-29.

[89] Salomão, R.P.; Brienza Júnior, S.; Santana, A.C. 2012. Análise da florística e estrutura de floresta primária visando a seleção de espécies-chave, através de análise multivariada, para a restauração de áreas mineradas em unidades de conservação. Revista Árvore, 36: 989-1008.

[90] Salomão, R.P.; Brienza Júnior, S.; Rosa, N.A. 2014. Dinâmica de reflorestamento em áreas de restauração após mineração em unidade de conservação na Amazônia. Revista Árvore, 38: 1-24.

[91] Santos, N.M.C. dos; Vale Jr., J.F. do; Barbosa, R.I. 2013. Florística e estrutura arbórea de ilhas de mata em áreas de savana do norte da Amazônia brasileira Boletim do Museu Paraense Emílio Goeldi (Ciências Naturais), 8: 205-221.

[92] Shimbu, G. Distribuição de grupos funcionais de plantas em microhabitats de clareiras. [s.d]. (http://pdbff.inpa.gov.br/). Accessed on 12/03/2016.

[93] Silva, A.F. Da; Oliveira, R.V. De; Santos, N.R.L.; Paula, A. De. 2003. Composição florística e grupos ecológicos das espécies de um trecho de floresta semidecídua submontana da Fazenda São Geraldo, Viçosa-MG. Revista Árvore, 27: 311-319.

[94] Silva, L.S. 2015. Padrões de venação foliar no gênero Parkia R.Br. (Leguminosae: Mimosoideae). Master's thesis. Instituto Nacional de Pesquisas da Amazônia, Manaus, 79p.

[95] Tanaka, A. 2005. Avaliação de anéis de crescimento de espécies florestais de terra-firme no município de Novo Aripuanã - AM. Doctoral thesis. Instituto Nacional de Pesquisas da Amazônia, 200p.

[96] UHE, Unidade Hidrelétrica Teles Pires. 2013. Lista de Espécies Alvo para Restauração Florestal (http://www.uhetelespires.com.br/). Accessed on 14/03/2016.

[97] Miguel, A.; Marimon, B.S.; Maracahipes, L.; Oliveira, E.A. de; Marimon Junior, B.H. 2011. Mudanças na estrutura da vegetação lenhosa em três porções da mata de galeria do Córrego Bacaba (1999-2006), Nova Xavantina-MT. Revista Árvore, 35: 725-735.

[98] da Silva, A.C.; Higuchi, P.; Negrini, M.; Grudtner, A.; Zech, D.F. 2013. Caracterização fitossociológica e fitogeográfica de um trecho de floresta ciliar em Alfredo Wagner, SC, como subsídio para restauração ecológica. Ciencia Florestal, 23: 579-593.

[99] Andrade, E.A.; Higuchi, N. 2009. Produtividade de quatro espécies arbóreas de Terra Firme da Amazônia Central. Acta Amazonica, $39: 105-112$.

[100] Maues, M.M. 2006. Estratégias reprodutivas de espécies arbóreas e sua importância para o manejo e a conservação florestal: Floresta Nacional do Tapajós (Beletera-Pará). Doctoral thesis. Universidade de Brasilia, Brasília, 206p.

[101] Silva, J.M. da. 2012. Floresta urbana: síndrome de dispersão e grupos ecológicos de espécies do sub-bosque. Boletim de Geografia, 31: 135-144.

[102] Vinson, C.C.; Kanashiro, M.; Harris, S.A.; Boshier, D.H. 2015. Impacts of selective logging on inbreeding and gene flow in two Amazonian timber species with contrasting ecological and reproductive characteristics. Molecular Ecology, 24: 38-53. 